Supporting Information for:

\title{
16-Electron Half-Sandwich Rhodium(III), Iridium(III) and Ruthenium(II) Complexes as Lysosome-Targeted Anticancer Agents
}

Jie Gao, Lihua Guo*, Yuting Wu, Yihan Cheng, Xueyan Hu, Jinfeng Liu, Zhe Liu*

Department of Chemistry and Chemical Engineering, Qufu Normal University, Qufu 273165, China.

*Corresponding Author: Email: guolihua@qfnu.edu.cn (L. Guo); liuzheqd@163.com (Z. Liu).

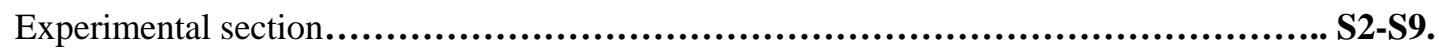

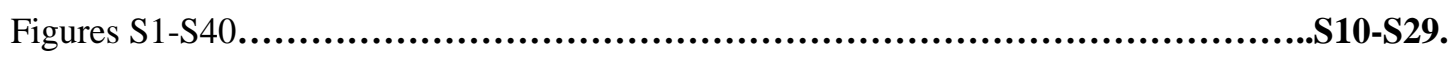

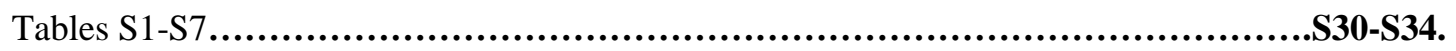




\section{EXPERIMENTAI SECTIONS}

\subsection{Materials and methods}

$\mathrm{RhCl}_{3} \cdot \mathrm{nH}_{2} \mathrm{O}, \quad \mathrm{IrCl}_{3} \cdot \mathrm{nH}_{2} \mathrm{O}, \quad \mathrm{RuCl}_{3} \cdot \mathrm{nH}_{2} \mathrm{O}, \quad$ 1,2,3,4,5-pentamethyl-cyclopentadiene(95\%), 2,3,4,5-tetramethyl-2-cyclopentenone(95\%), phenylmagnesium bromide, $\alpha$-terpinene, 1-bromo-2-fluorobenzene, 1-bromo-3,5-bis(trifluoromethyl)benzene, 9-methyladenine and 9-ethylguanine were purchased from Sigma-Aldrich and used without further purification unless otherwise specified. 1- (2,3,4,5-tetramethylcyclopenta- 1,3-dien-1-yl) - 3,5-bis (trifluoromethyl) benzene, 1-fluoro-2-(2,3,4,5-tetramethylcyclopenta -1,3-dien-1-yl) benzene, $\left[\left(\eta^{5}-\mathrm{Cp}^{\mathrm{R} 1}\right) \mathrm{RhCl}_{2}\right]_{2}$ $\left(\mathrm{Cp}^{\mathrm{R} 1}=\mathrm{C}_{5}\left(\mathrm{CH}_{3}\right)_{4} \mathrm{R}_{1}, \mathrm{R}_{1}=\mathrm{CH}_{3}, \mathrm{Ph}\right),\left[\left(\eta^{5}-\mathrm{C}_{5}\left(\mathrm{CH}_{3}\right)_{5}\right) \mathrm{IrCl}_{2}\right]_{2},\left[\left(\eta^{6}-\mathrm{p} \text {-cymene }\right) \mathrm{RuCl}_{2}\right]_{2}$ and were synthesized according to previous reported procedures ${ }^{1-4}$. For the biological experiments, DMEM medium, fetal bovine serum, penicillin/streptomycinmixture, trypsin/EDTA, cisplatin, MTT and phosphate-buffered saline (PBS) were purchased from Sangon Biotech. Testing compounds was dissolved in DMSO and diluted with the tissue culture medium before use.

All manipulations involving air- and moisture-sensitive compounds were carried out under an atmosphere of dried and purified nitrogen with standard vacuum-line Schlenk techniques. ${ }^{1} \mathrm{H}$ NMR spectra were acquired in $5 \mathrm{~mm}$ NMR tubes at $25{ }^{\circ} \mathrm{C}$ on Bruker DPX 500 using TMS as an internal standard and $\mathrm{CDCl}_{3}$ as solvent. Mass spectra of complexes Rh1-Rh5, Ir1 and Ru1 were recorded on a Thermo LTQ Orbitrap XL $\left(\mathrm{ESI}^{+}\right)$. X-ray Diffraction data were obtained on a Bruker Apex SMART CCD area detector with graphite-monochromated Mo K $\alpha$ radiation $(\lambda=0.71073$ $\AA)$.

\subsection{Synthesis of $\mathrm{L} 1$}

Meta-chloroperbenzoic acid (60 wt\% with water, $5.5 \mathrm{~g}, 19 \mathrm{mmol}$ ) was dissolved in dichloromethane $(60 \mathrm{~mL})$, dried over $\mathrm{Na}_{2} \mathrm{SO}_{4}$ and degased with a gentle stream of argon. This solution was added to a dichloromethane $(200 \mathrm{~mL})$ solution of NacNac precursor $(3.48 \mathrm{~g}, 9.6$ mmol). The reaction mixture was stirred for one hour. The organic phase was washed with saturated aqueous solutions of $\mathrm{NaHCO}_{3}(3 \times 200 \mathrm{~mL})$, water $(1 \times 200 \mathrm{~mL})$, dried over $\mathrm{Na}_{2} \mathrm{SO}_{4}$ and concentrated in vacuo, yielding $\mathbf{L} 1$ as a yellow powder (1.47 g, 40.7\% yield). ${ }^{1} \mathrm{H}$ NMR (500 MHz, $\left.\mathrm{CDCl}_{3}\right) \delta 7.12-7.05(\mathrm{~m}, 6 \mathrm{H}, \mathrm{Ar}-\mathrm{H}), 2.46-2.28\left(\mathrm{~m}, 8 \mathrm{H}, \mathrm{CH}_{2} \mathrm{CH}_{3}\right), 1.95\left(\mathrm{~m}, 6 \mathrm{H}, \mathrm{N}=\mathrm{CCH}_{3}\right), 1.13$ $-1.10\left(\mathrm{~m}, 12 \mathrm{H}, \mathrm{CH}_{2} \mathrm{CH}_{3}\right) .{ }^{13} \mathrm{C} \mathrm{NMR}\left(100 \mathrm{MHz}, \mathrm{CDCl}_{3}\right) \delta: 192.46,167.12,144.89,129.91,124.94$, 123.20, 23.21, 215.36, 12.95. ESI-MS (m/z): calcd for $\mathrm{C}_{25} \mathrm{H}_{33} \mathrm{O}_{1} \mathrm{~N}_{2}: 377.2593$, found: 377.2000 
$[\mathrm{M}+\mathrm{H}]^{+}$. Anal. calcd for $\mathrm{C}_{25} \mathrm{H}_{32} \mathrm{O}_{1} \mathrm{~N}_{2}: \mathrm{C}, 79.74 ; \mathrm{H}, 8.57 ; \mathrm{N}, 7.44$. Found: $\mathrm{C}, 79.72 ; \mathrm{H}, 8.54 ; \mathrm{N}$ 7.42 .

\subsection{Synthesis of $L 2$}

Meta-chloroperbenzoic acid (60 wt\% with water, $2.3 \mathrm{~g}, 13.4 \mathrm{mmol}$ ) was dissolved in dichloromethane $(60 \mathrm{~mL})$, dried over $\mathrm{Na}_{2} \mathrm{SO}_{4}$ and degased with a gentle stream of argon. This solution was added to a dichloromethane $(200 \mathrm{~mL})$ solution of NacNac precursor $(2.8 \mathrm{~g}, 6.8$ mmol). The reaction mixture was stirred for one hour. The organic phase was washed with saturated aqueous solutions of $\mathrm{NaHCO}_{3}(3 \times 200 \mathrm{~mL})$, water $(1 \times 200 \mathrm{~mL})$, dried over $\mathrm{Na}_{2} \mathrm{SO}_{4}$ and concentrated in vacuo, yielding $\mathbf{L} 2$ as a yellow powder (1.33 g, 45.4\% yield). ${ }^{1} \mathrm{H}$ NMR (500 MHz, $\left.\mathrm{CDCl}_{3}\right) \delta 7.22-7.07(\mathrm{~m}, 6 \mathrm{H}), 2.81\left(\mathrm{~m}, 1 \mathrm{H}, \mathrm{CH}\left(\mathrm{CH}_{3}\right)_{2}\right), 1.99\left(\mathrm{~s}, 6 \mathrm{H}, \mathrm{N}=\mathrm{CCH}_{3}\right), 1.13(\mathrm{~m}, 24 \mathrm{H}$, $\left.\mathrm{CH}\left(\mathrm{CH}_{3}\right)_{2}\right)$. This compound is previous known. ${ }^{5}$

\subsection{Synthesis of $\mathrm{L3}$}

Meta-chloroperbenzoic acid (60 wt\% with water, $1.1 \mathrm{~g}, 3.8 \mathrm{mmol}$ ) was dissolved in dichloromethane $(60 \mathrm{~mL})$, dried over $\mathrm{Na}_{2} \mathrm{SO}_{4}$ and degased with a gentle stream of argon. This solution was added to a dichloromethane $(200 \mathrm{~mL})$ solution of NacNac precursor $(1.9 \mathrm{~g}, 1.9$ mmol). The reaction mixture was stirred for one hour. The organic phase was washed with saturated aqueous solutions of $\mathrm{NaHCO}_{3}(3 \times 200 \mathrm{~mL})$, water $(1 \times 200 \mathrm{~mL})$, dried over $\mathrm{Na}_{2} \mathrm{SO}_{4}$ and concentrated in vacuo, yielding $\mathbf{L 3}$ as a yellow powder (0.836 g, 44.5\% yield). ${ }^{1} \mathrm{H}$ NMR (500 $\left.\mathrm{MHz}, \mathrm{CDCl}_{3}\right) \delta 7.16(\mathrm{~m}, 32 \mathrm{H}), 6.98-6.92(\mathrm{~m}, 8 \mathrm{H}), 6.46(\mathrm{~s}, 4 \mathrm{H}),, 5.49\left(\mathrm{~s}, 4 \mathrm{H}, \mathrm{CH}\left(\mathrm{CH}_{3}\right)_{2}\right), 3.54(\mathrm{~s}$, 6H, OMe), $0.24\left(\mathrm{~s}, 6 \mathrm{H}, \mathrm{N}=\mathrm{CCH}_{3}\right) .{ }^{13} \mathrm{C}$ NMR $\left(126 \mathrm{MHz}, \mathrm{CDCl}_{3}\right) \delta 190.48,171.18,155.79,143.79$, $141.71,141.17,133.19,129.83,128.54,128.46$ - 128.42, 128.25, 126.62, 126.29, 114.34, 55.22, 52.08, 29.78, 16.50. ESI-MS (m/z): calcd for $\mathrm{C}_{71} \mathrm{H}_{61} \mathrm{O}_{3} \mathrm{~N}_{2}: 989.4682$, found: $989.4668[\mathrm{M}+\mathrm{H}]^{+}$. Anal. calcd for $\mathrm{C}_{71} \mathrm{H}_{60} \mathrm{O}_{3} \mathrm{~N}_{2}$ : C, 86.20; H, 6.11; N, 2.83. Found: C, 86.18; H, 6.13; N, 2.81 .

\subsection{Synthesis of D3}

D3 was synthesized using a microwave synthesizer and $100 \mathrm{~mL}$ microwave vials. $\mathrm{RhCl}_{3} \cdot \mathrm{nH}_{2} \mathrm{O}$ (0.3 g, $1.4 \mathrm{mmol}), \mathrm{Cp}^{\mathrm{R} 1}\left(\mathrm{Cp}^{\mathrm{R} 1}=\mathrm{C}_{5}\left(\mathrm{CH}_{3}\right)_{4} \mathrm{R}_{1}, \mathrm{R}_{1}=\right.$ 2-fluorobenzene) $(0.6 \mathrm{~g}, 2.8 \mathrm{mmol}), 14 \mathrm{~mL}$ of methanol were add in a microwavevial. The reaction is carried out under nitrogen protection. The vial was placed in the microwave instrument, and the reaction conditions were heated to $120{ }^{\circ} \mathrm{C}$ and reacted for $40 \mathrm{~min}$. After performing the microwave reaction, yielding an red solution, the reaction mixture was allowed to cool to ambient temperature and the solvents evaporated to 
dryness on a rotary evaporator. Add $\mathrm{CH}_{2} \mathrm{Cl}_{2}$ to dissolve, then filtered. The filtrate volume was slowly reduced to a little on a rotary evaporator and diethyl ether was added. Freezing at low temperature, an red precipitate appeared and was collected by filtration. The product was washed with diethyl ether and dried in air. D3 Red solid, yield: $311.0 \mathrm{mg}$ (57.1\%). ${ }^{1} \mathrm{H}$ NMR (500 MHz, $\left.\mathrm{CDCl}_{3}\right) \delta 8.30-8.27(\mathrm{~m}, 2 \mathrm{H}, \mathrm{Ar}-H), 7.41-7.38(\mathrm{~m}, 2 \mathrm{H}, \mathrm{Ar}-H), 7.28-7.26(\mathrm{~m}, 2 \mathrm{H}, \mathrm{Ar}-H), 7.05-$ $7.01(\mathrm{~m}, 2 \mathrm{H}, \mathrm{Ar}-\mathrm{H}), 1.74\left(\mathrm{~s}, 12 \mathrm{H}, \mathrm{Cp}^{\mathrm{R} 1}-\mathrm{CH}_{3}\right), 1.64\left(\mathrm{~s}, 12 \mathrm{H}, \mathrm{Cp}^{\mathrm{R} 1}-\mathrm{CH}_{3}\right) .{ }^{19} \mathrm{~F}$ NMR $(471 \mathrm{MHz}$, $\left.\mathrm{CDCl}_{3}\right) \delta$-114.97. ESI-MS (m/z): calcd for $\mathrm{C}_{15} \mathrm{H}_{16} \mathrm{FRh:} 318.0291$, found: 318.3019 [0.5M-2Cl] ${ }^{+}$. Anal. calcd for $\mathrm{C}_{30} \mathrm{H}_{32} \mathrm{Cl}_{4} \mathrm{~F}_{2} \mathrm{Rh}_{2}$ : C, 46.30; H, 4.14. Found: C, 46.28; H, 4.12.

\subsection{Synthesis of D4}

D4 was synthesized using a microwave synthesizer and $100 \mathrm{~mL}$ microwave vials. $\mathrm{RhCl}_{3} \cdot \mathrm{nH}_{2} \mathrm{O}$ (0.3 g, $1.4 \mathrm{mmol}), \mathrm{Cp}^{\mathrm{R} 1}\left(\mathrm{Cp}^{\mathrm{R} 1}=\mathrm{C}_{5}\left(\mathrm{CH}_{3}\right)_{4} \mathrm{R}_{1}, \mathrm{R}_{1}=3,5\right.$-bis (trifluoromethyl) benzene) (0.9 g, 2.8 $\mathrm{mmol}$ ), $14 \mathrm{~mL}$ of methanol were add in a microwave vial. The reaction is carried out under nitrogen protection. The vial was placed in the microwave instrument, and the reaction conditions were heated to $120{ }^{\circ} \mathrm{C}$ and reacted for $40 \mathrm{~min}$. After performing the microwave reaction, yielding an red solution, the reaction mixture was allowed to cool to ambient temperature and the solvents

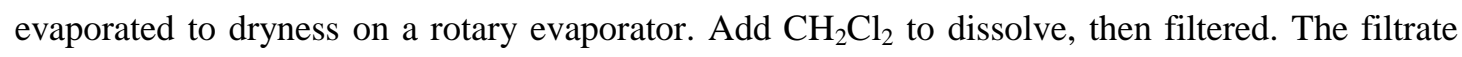
volume was slowly reduced to a little on a rotary evaporator and diethyl ether was added. Freezing at low temperature, a red precipitate appeared and was collected by filtration. The product was washed with diethyl ether and dried in air. D4 Red solid, yield: $429.5 \mathrm{mg}(60.5 \%)$. ${ }^{1} \mathrm{H}$ NMR (500 $\left.\mathrm{MHz}, \mathrm{CDCl}_{3}\right) \delta 8.21(\mathrm{~m}, 4 \mathrm{H}), 7.94(\mathrm{~m}, 2 \mathrm{H}), 1.75\left(\mathrm{~s}, 12 \mathrm{H}, \mathrm{Cp}^{\mathrm{R} 1}-H\right), 1.70\left(\mathrm{~s}, 12 \mathrm{H}, \mathrm{Cp}^{\mathrm{R} 1}-H\right) .{ }^{19} \mathrm{~F}$ NMR (471 MHz, $\left.\mathrm{CDCl}_{3}\right) \delta$-62.82. ESI-MS (m/z): calcd for $\mathrm{C}_{17} \mathrm{H}_{16} \mathrm{~F}_{6} \mathrm{Rh}$ : 437.0211, found: $437.1967[0.5 \mathrm{M}-2 \mathrm{Cl}+\mathrm{H}]^{+}$. Anal. calcd for $\mathrm{C}_{34} \mathrm{H}_{30} \mathrm{Cl}_{4} \mathrm{~F}_{12} \mathrm{Rh}_{2}: \mathrm{C}, 40.27 ; \mathrm{H}, 2.98$. Found: $\mathrm{C}, 40.25 ; \mathrm{H}$, 2.95 .

\subsection{X-ray Crystallography}

All diffraction data were obtained on a Bruker Smart Apex CCD diffractometer equipped with graphite-monochromated Mo K $\alpha$ radiation. Absorption corrections were applied using SADABS program. The crystals were mounted in oil and held at $-173{ }^{\circ} \mathrm{C}$ with the Oxford Cryosystem Cobra. The structures were solved by direct methods using SHELXS (TREF) with additional light atoms found by Fourier methods. Complexes were refined against F2 using SHELXL, and hydrogen atoms were added at calculated positions and refined riding on their parent atoms. X-ray 
crystallographic data for $\mathbf{R h} \mathbf{2}$ is available as Figure 1, Table S1 and Table S2 and have been deposited in the Cambridge Crystallographic Data Centre under the accession number 2090684. X-ray crystallographic data for Ir 1 is available as Figure 1, Table S3, and Table S4 have been deposited in the Cambridge Crystallographic Data Centre under the accession number 2090683. X-ray crystallographic data in CIF format are available from the Cambridge Crystallographic Data Centre (http://www.ccdc.cam.ac.uk/). Notably, there are some disorders in the crystal structure of Ir1 (Figure S40). Differential electron density peak was used to determine the model. Necessary restriction was adopted to refine the occupation to be 0.55353 and 0.44647 respectively. Symmetry transformations used to generate equivalent atoms have been listed in Table S5.

\subsection{NMR Spectroscopy}

${ }^{1} \mathrm{H}$ NMR spectra were acquired in $5 \mathrm{~mm}$ NMR tubes at $25{ }^{\circ} \mathrm{C}$ on Bruker DPX $500\left({ }^{1} \mathrm{H}=500.13\right.$ MHz). ${ }^{1} \mathrm{H}$ NMR chemical shifts were internally referenced to TMS (0 ppm) for $\mathrm{CDCl}_{3}$ or DMSO- $d_{6} / \mathrm{D}_{2} \mathrm{O}$ respectively. All data processing was carried out using XWIN-NMR version 3.6 (Bruker UK Ltd.).

\subsection{Solution stability studies}

Solutions of complexes Rh1-Rh5, Ir1 and Ru1 with final concentration of $0.5 \mathrm{mM}$ in $75 \%$ DMSO- $d_{6} / 25 \%$ phosphate-buffered saline (PBS) $\left(\mathrm{pH} \approx 7.2\right.$, PBS is prepared from $\mathrm{D}_{2} \mathrm{O}$ ) was monitored by ${ }^{1} \mathrm{H}$ NMR. ${ }^{1} \mathrm{H}$ NMR spectra were recorded after various time intervals at $25{ }^{\circ} \mathrm{C}$.

\subsection{Interaction with Nucleobases and DNA binding}

The reaction of complex Rh5 (ca. $1 \mathrm{mM}$ ) with nucleobases typically involved addition of a solution containing 1 mol equiv. of nucleobase in $\mathrm{D}_{2} \mathrm{O}$ to an solution of complex $\mathbf{R h 5}$ in $70 \%$ DMSO- $\mathrm{d}_{6} / 30 \% \mathrm{D}_{2} \mathrm{O}(\mathrm{v} / \mathrm{v})$, respectively. ${ }^{1} \mathrm{H}$ NMR spectra of these solutions were recorded at $25{ }^{\circ} \mathrm{C}$ after various time intervals.

The concentration of CT-DNA was determined by the absorption intensity at $260 \mathrm{~nm}$, and its molar absorption coefficient $\left(\varepsilon_{260}\right)$ is $6600 \mathrm{~L} \cdot \mathrm{cm}^{-1} \cdot \mathrm{mol}^{-1}$. Weigh an appropriate amount of the sample to be tested, dissolve it in DMSO and configure it to $100 \mathrm{mM}$. Store the solution in $4{ }^{\circ} \mathrm{C}$ refrigerator. At room temperature, add $5 \mathrm{mM}$ Tris- $\mathrm{HCl} / 10 \mathrm{mM} \mathrm{NaCl}(\mathrm{pH}=7.2)$ buffer to the cuvette, the sample to be tested and a certain proportion of CT-DNA solution. The CT-DNA solution gradually increases, and mix well after each drop. After reacting the sample with CT-DNA for $5 \mathrm{~min}$, the UV absorption spectrum of the system was scanned and recorded in the 
range of 200-450 $\mathrm{nm}$. The interaction between the complex and CT-DNA was fitted to Benesi-Hildebrand equation to calculate the binding constant $\mathrm{K}_{\mathrm{b}}$.

$$
\frac{A_{o}}{\left(A-A_{O}\right)}=\frac{\varepsilon_{f}}{\left(\varepsilon_{b}-\varepsilon_{f}\right)}+\frac{\varepsilon_{f}}{K_{b}\left(\varepsilon_{b}-\varepsilon_{f}\right)[D N A]}
$$

Among them $\varepsilon_{\mathrm{b}}$ and $\varepsilon_{\mathrm{f}}$ is the extinction coefficient of bound and free-form complexes, respectively. $\mathrm{A}_{0}$ is the initial absorbance of the free complex, and $\mathrm{A}$ is the absorbance of the compound in the presence of DNA. $\mathrm{A}_{0} /\left(\mathrm{A}-\mathrm{A}_{0}\right)$ gives a straight line for the curve of $1 /[\mathrm{DNA}]$, and the binding constant $\left(\mathrm{K}_{\mathrm{b}}\right)$ is calculated as the intercept/slope ratio.

\subsection{Measurement of Lipophilicity}

The octanol-water partition coefficients (P) of Rh1-Rh5, Ir1 and Ru1 were determined using a shake-flask method. Water (50 mL, distilled after milli-Q purification) and 1-octanol $(50 \mathrm{~mL}$, vacuum distilled) were shaken together using a laboratory shaker, for $72 \mathrm{~h}$ to allow saturation of both phases. Stock solutions of the three complexes $(50 \mu \mathrm{M})$ were prepared in the aqueous phase and aliquots $(5 \mathrm{~mL})$ of each of these stock solutions were then added to an equal volume of the 1-octanol phase. The resultant biphasic solutions were mixed for $2 \mathrm{~h}$ and then centrifuged ( $3000 \times$ g, 5 min) to separate the phases. The concentrations of the complex in the organic and aqueous phases were then determined using UV-vis $(260 \mathrm{~nm})$. Log P was defined as the logarithm of the ratio of the concentrations of the complex in the organic and aqueous phases $(\log \mathrm{P}=\log$; values reported are the means of three separate determinations).

\subsection{UV-vis Spectroscopy}

The UV-vis spectra of the compounds were recorded by TU-1901 UV spectrophotometer with 1 cm path-length quartz cuvettes $(3 \mathrm{~mL})$. Spectra were processed using UVWinlab software. Experiments were carried out at $37^{\circ} \mathrm{C}$ unless otherwise stated.

\subsection{Determination of Absolute quantum yields}

Complexes were diluted to $10 \mu \mathrm{M}$ for absolute quantum yield (QY), and measurement using fluorometer (Edinburgh, FLS 1000). For Rh1-Rh5 and Ir1: $\lambda_{\mathrm{ex}}=365 \mathrm{~nm}, \mathbf{R u 1}: \lambda_{\mathrm{ex}}=377 \mathrm{~nm}$.

\subsection{Cell Culture Conditions}

Human cancer cells (lung cancer A549 cells and cervical carcinoma HeLa) were obtained from Shanghai Institute of Biochemistry. The cells were maintained in DMEM (Dulbecco's modified Eagle's medium, Gibco BRL) or RPMI 1640 (Roswell Park Memorial Institute 1640, Gibco BRL) 
medium, which contained 10\% FBS (fetal bovine serum, Gibco BRL), $100 \mu \mathrm{g} \mathrm{mL}^{-1}$ streptomycin, and $100 \mathrm{U} \mathrm{mL}^{-1}$ penicillin (Gibco BRL). The cells were cultured in a humidified incubator, which provided an atmosphere of $5 \% \mathrm{CO}_{2}$ and $95 \%$ air at a constant temperature of $37{ }^{\circ} \mathrm{C}$. In each experiment, cells treated with vehicle only DMSO $(1 \%, \mathrm{v} / \mathrm{v})$ were used as the reference group.

\subsection{Cellular uptake (ICP-MS)}

A549 cells were seeded in $10 \mathrm{~cm}$ tissue culture dishes and incubated for $24 \mathrm{~h}$. The media was removed and replaced with fresh media containing the tested complexes. After $24 \mathrm{~h}$ incubation, the cells were washed with PBS, trypsinized and collected. The cells were counted, and digested with $\mathrm{HNO}_{3}(65 \%, 0.2 \mathrm{~mL})$ at room temperature for $24 \mathrm{~h}$. The solution was then diluted to a final volume of $10 \mathrm{~mL}$ with Milli-Q water. The concentration of rhodium complex was measured using the XSERIES 2 ICP-MS.

\subsection{Determination of $\mathrm{IC}_{50}$ value (MTT assay)}

After plating 5000 cells per well in 96-well plates, the cells were preincubated in drug-free media at $37{ }^{\circ} \mathrm{C}$ for $48 \mathrm{~h}$ or $72 \mathrm{~h}$ before adding different concentrations of the compounds to be tested. In order to prepare the stock solution of the drug, the solid complex was dissolved in DMSO. This stock was further diluted using cell culture medium until working concentrations were achieved. The drug exposure period was $48 \mathrm{~h}$. Subsequently, $15 \mu \mathrm{L}$ of $5 \mathrm{mg} \mathrm{mL}^{-1}$ MTT solution was added to form a purple formazan. Afterwards, $100 \mu \mathrm{L}$ of dimethyl sulfoxide (DMSO) was transferred into each well to dissolve the purple formazan, and results were measured using a microplate reader (DNM-9606, Perlong Medical, Beijing, China) at an absorbance of $570 \mathrm{~nm}$. Each well was triplicated and each experiment repeated at least three times. $\mathrm{IC}_{50}$ values quoted are mean $\pm \mathrm{SEM}$.

\subsection{Cell Cycle Analysis}

A549 cells at $1.5 \times 10^{6}$ per well were seeded in a six-well plate. Cells were preincubated in drug-free media at $37{ }^{\circ} \mathrm{C}$ for $48 \mathrm{~h}$, after which drugs were added at concentrations of $0.25 \times \mathrm{IC}_{50}$, $0.5 \times \mathrm{IC}_{50}$ and $1 \times \mathrm{IC}_{50}$ of complex $\mathbf{R h 5}$ against A549 cancer cells. After $48 \mathrm{~h}$ of drug exposure, supernatants were removed by suction and cells were washed with PBS. Finally, cells were harvested using trypsin-EDTA and fixed for $24 \mathrm{~h}$ using cold $70 \%$ ethanol. DNA staining was achieved by resuspending the cell pellets in PBS containing propidium iodide (PI) and RNAse. Cell pellets were washed and resuspended in PBS before being analyzed in a flow cytometer 
(ACEA NovoCyte, Hangzhou, China) using excitation of DNA-bound PI at $488 \mathrm{~nm}$, with emission at $585 \mathrm{~nm}$. Data were processed using NovoExpress software. The cell cycle distribution is shown as the percentage of cells containing $\mathrm{G}_{1}, \mathrm{~S}$ and $\mathrm{G}_{2} / \mathrm{M}$ DNA as identified by propidium iodide staining.

\subsection{Induction of Apoptosis}

Flow cytometry analysis of apoptotic populations of A549 cells caused by exposure to complex Rh5 was carried out using the Annexin V-FITC Apoptosis Detection Kit (Beyotime Institute of Biotechnology, China) according to the supplier's instructions. Briefly, $1.5 \times 10^{6}$ A549 cells per well were seeded in a six-well plate. Cells were preincubated in drug-free media at $37{ }^{\circ} \mathrm{C}$ for $48 \mathrm{~h}$, after which drugs were added at concentrations of $0.5 \times \mathrm{IC}_{50}$ and $1 \times \mathrm{IC}_{50}$. After $48 \mathrm{~h}$ of drug exposure, cells were collected, washed once with PBS, and resuspended in $195 \mu \mathrm{L}$ of annexin V-FITC binding buffer which was then added to $5 \mu \mathrm{L}$ of annexin V-FITC and $10 \mu \mathrm{L}$ of PI, and then incubated at room temperature in the dark for $15 \mathrm{~min}$. Subsequently, the buffer placed in an ice bath in the dark. The samples were analyzed by a flow cytometer (ACEA NovoCyte, Hangzhou, China). Cells for apoptosis studies were used with no previous fixing procedure as to avoid nonspecific binding of the annexin V-FITC conjugate.

\subsection{The Cellular Uptake Mechanism}

A549 cells were seeded in 6-well plates for $48 \mathrm{~h}$ and preincubated with $\mathrm{CCCP}(50 \mu \mathrm{M})$ or chloroquine $(50 \mu \mathrm{M})$ for $1 \mathrm{~h}$. The medium was removed and the cells were then incubated with Rh5 $(2 \mu \mathrm{M})$ for $1 \mathrm{~h}$. To investigate the impact of temperature on cellular uptake, the cells were incubated at $4{ }^{\circ} \mathrm{C}$ or $37{ }^{\circ} \mathrm{C}$ for $1 \mathrm{~h}$. In each case, the cells were washed three times with ice-cold PBS and visualize by confocal microscopy (LSM 880 NLO, Carl Zeiss, Göttingen, Germany) immediately.

\subsection{Colocalization Assay}

A549 cells were incubated with complex $\mathbf{R h 5}(2 \mu \mathrm{M})$ for $1 \mathrm{~h}$ at $37{ }^{\circ} \mathrm{C}$, then co-incubated with MTDR (500 nM) and LTDR (75 nM) for $0.5 \mathrm{~h}$, respectively. Rh5 was excited at $405 \mathrm{~nm}$ and the emission was collected at $430-580 \mathrm{~nm}$. MTDR was excited at $644 \mathrm{~nm}$ and the emission was collected at $660-720 \mathrm{~nm}$; LTDR was excited at $594 \mathrm{~nm}$ and the emission was collected at $600-660$ nm. Cells were washed three times with PBS and visualized by confocal microscopy (LSM 880 NLO, Carl Zeiss, Göttingen, Germany). 


\subsection{Lysosomal Damage}

A549 cells seeded into six-well plate (Corning) were exposed to complex Rh5 at the indicated concentrations for $12 \mathrm{~h}$. The cells were then washed twice with PBS and incubated with AO $(5 \mu \mathrm{M})$ at $37{ }^{\circ} \mathrm{C}$ for $15 \mathrm{~min}$. The cells were washed twice with PBS and visualized by confocal microscopy (LSM/880NLO). Emission was collected at $510 \pm 20 \mathrm{~nm}$ (green) and $625 \pm 20 \mathrm{~nm}$ (red) upon excitation at $488 \mathrm{~nm}$.

\subsection{Detection of cathepsin B release}

Cathepsin B activity was detected using the fluorogenic susbtrate Magic Red MR-(RR)2 (Immunochemistry Tech, Bloomington, USA) according to the manufacturer's instructions. Briefly, A549 cells seeded into six-well plate (Corning) were exposed to Rh5 at the indicated concentrations for $12 \mathrm{~h}$ and then irradiated with a $425 \mathrm{~nm}$ LED light array for $15 \mathrm{~min}$. The media was removed and the cells were washed twice with PBS and then incubated with cathepsin B substrate at $37{ }^{\circ} \mathrm{C}$ for $1 \mathrm{~h}$. The media was removed and the cells were washed twice with PBS and visualized by confocal microscopy (LSM/880NLO). Emission was collected at $630 \pm 20 \mathrm{~nm}$ upon excitation at $543 \mathrm{~nm}$.

\section{References}

1. Yang, D.; Long, Y.; Wang, H.; Zhang, Z., Iridium-Catalyzed Asymmetric Ring-Opening Reactions of N-Boc-azabenzonorbornadiene with Secondary Amine Nucleophiles. Org. Lett. 2008, $10(21), 4723-4726$.

2. Wang, C.; Liu, J.; Tian, Z.; Tian, M.; Tian, L.; Zhao, W.; Liu, Z., Half-sandwich iridium N-heterocyclic carbene anticancer complexes. Dalton Trans. 2017, 46 (21), 6870-6883.

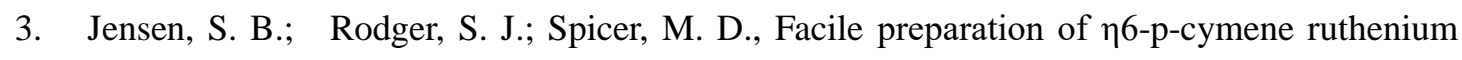
diphosphine complexes. Crystal structure of $\left[\left(\eta^{6}-\right.\right.$-p-cymene $)$ Ru(dppf)Cl]PF6. J. Org. Chem. 1998, $556(1), 151-158$.

4. Azoulay, J. D.; Rojas, R. S.; Serrano, A. V.; Ohtaki, H.; Galland, G. B.; Wu, G.; Bazan, G. C., Nickel $\alpha$-Keto- $\beta$-Diimine Initiators for Olefin Polymerization. Angew. Chem. Int. Ed. 2009, 48 (6), 1089-1092.

5. Tripathi, M.; Regnier, V.; Ziani, Z.; $\quad$ Devillard, M.; Philouze, C.; Martin, D., Metal free oxidation of vinamidine derivatives: a simple synthesis of $\alpha$-keto- $\beta$-diimine ligands. RSC Adv. 2018, 8 (67), 38346-38350. 


\section{NMR SPECTURE DATA}

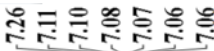
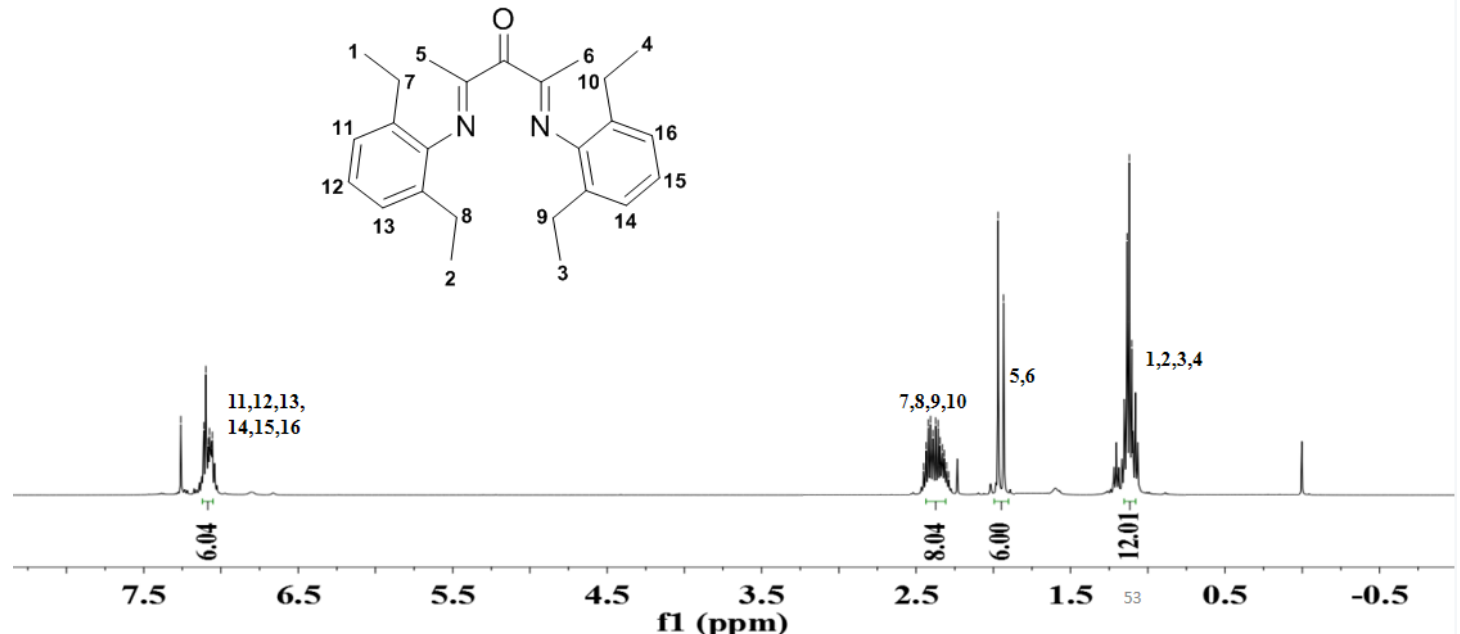

Figure S1. ${ }^{1} \mathrm{H}$ NMR spectrum of $\mathbf{L 1}$ in $\mathrm{CDCl}_{3}$.

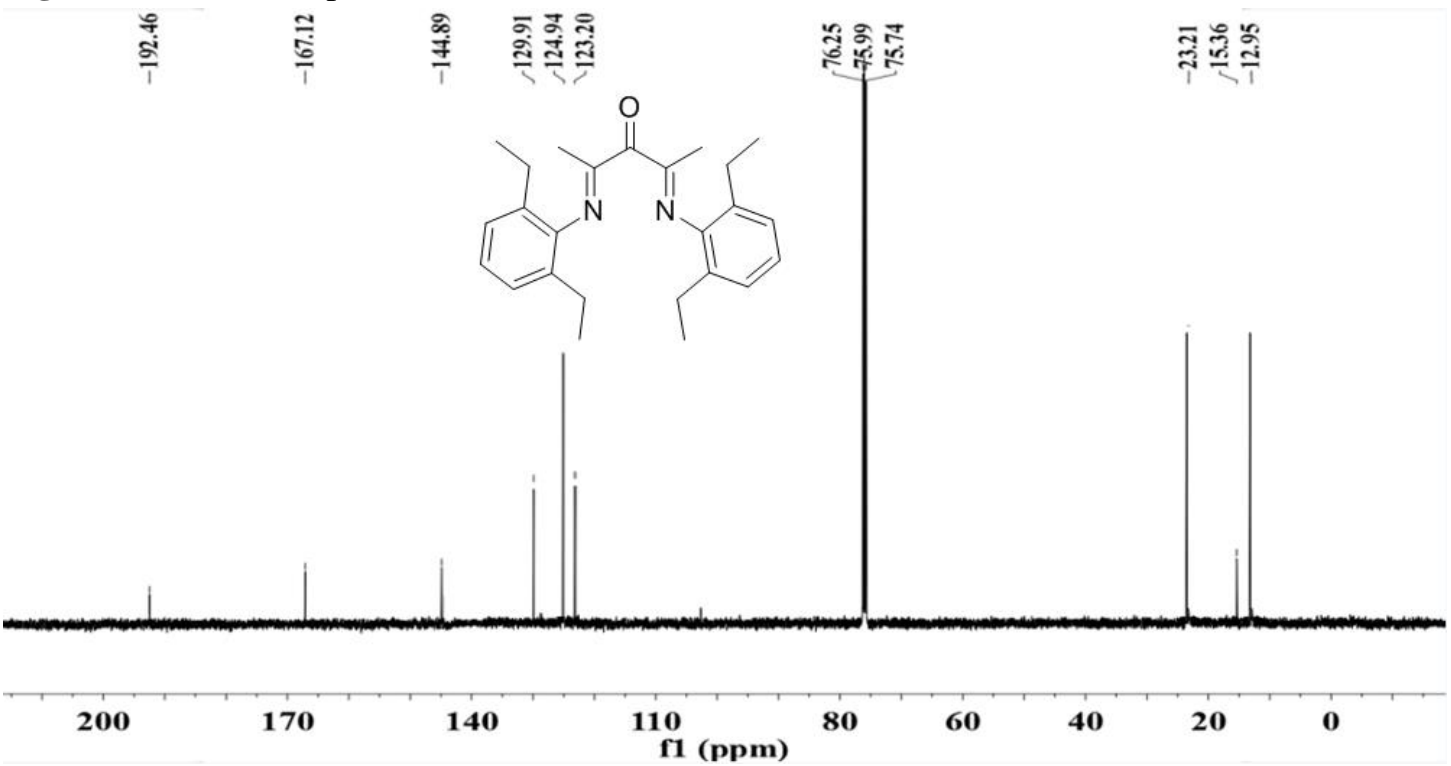

Figure S2. ${ }^{13} \mathrm{C}$ NMR spectrum of $\mathbf{L 1}$ in $\mathrm{CDCl}_{3}$. 


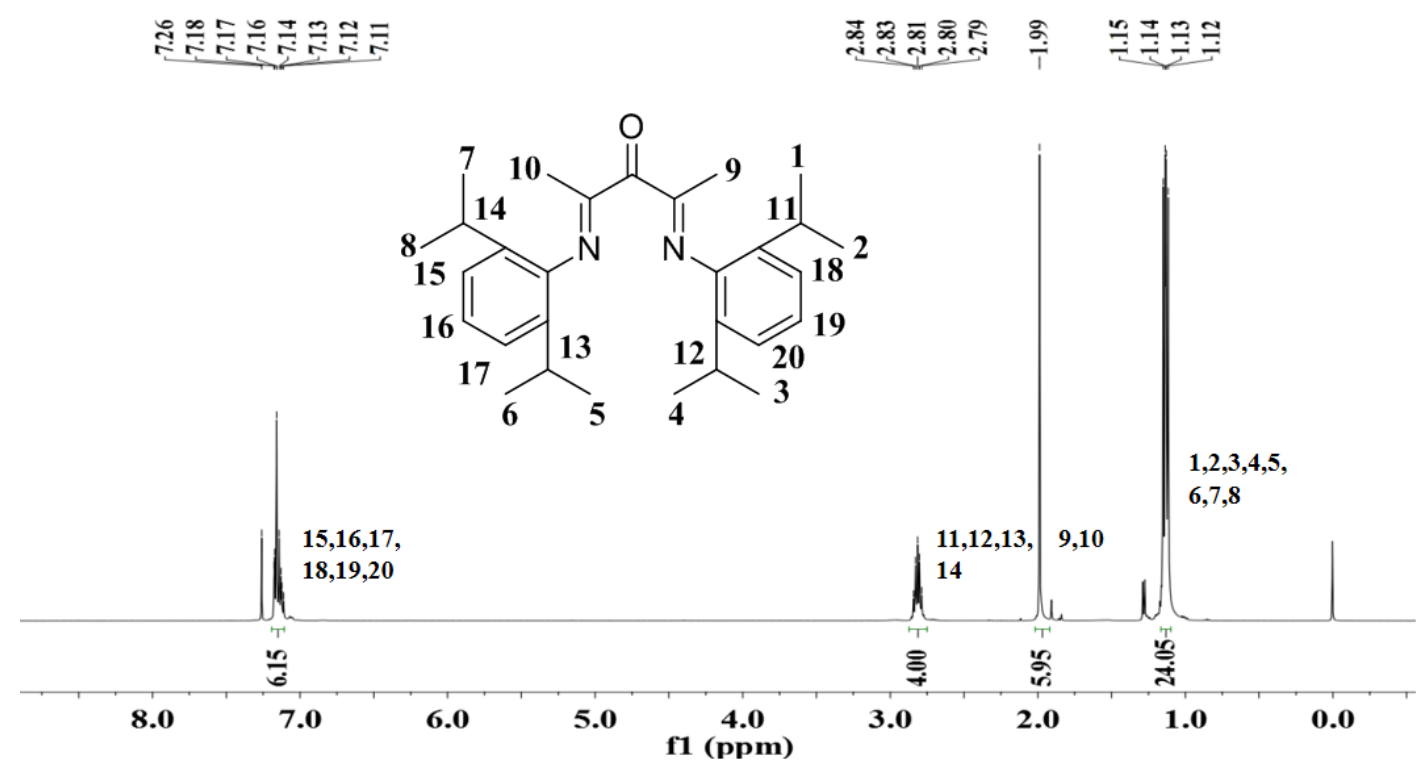

Figure S3. ${ }^{1} \mathrm{H}$ NMR spectrum of $\mathbf{L} 2$ in $\mathrm{CDCl}_{3}$.

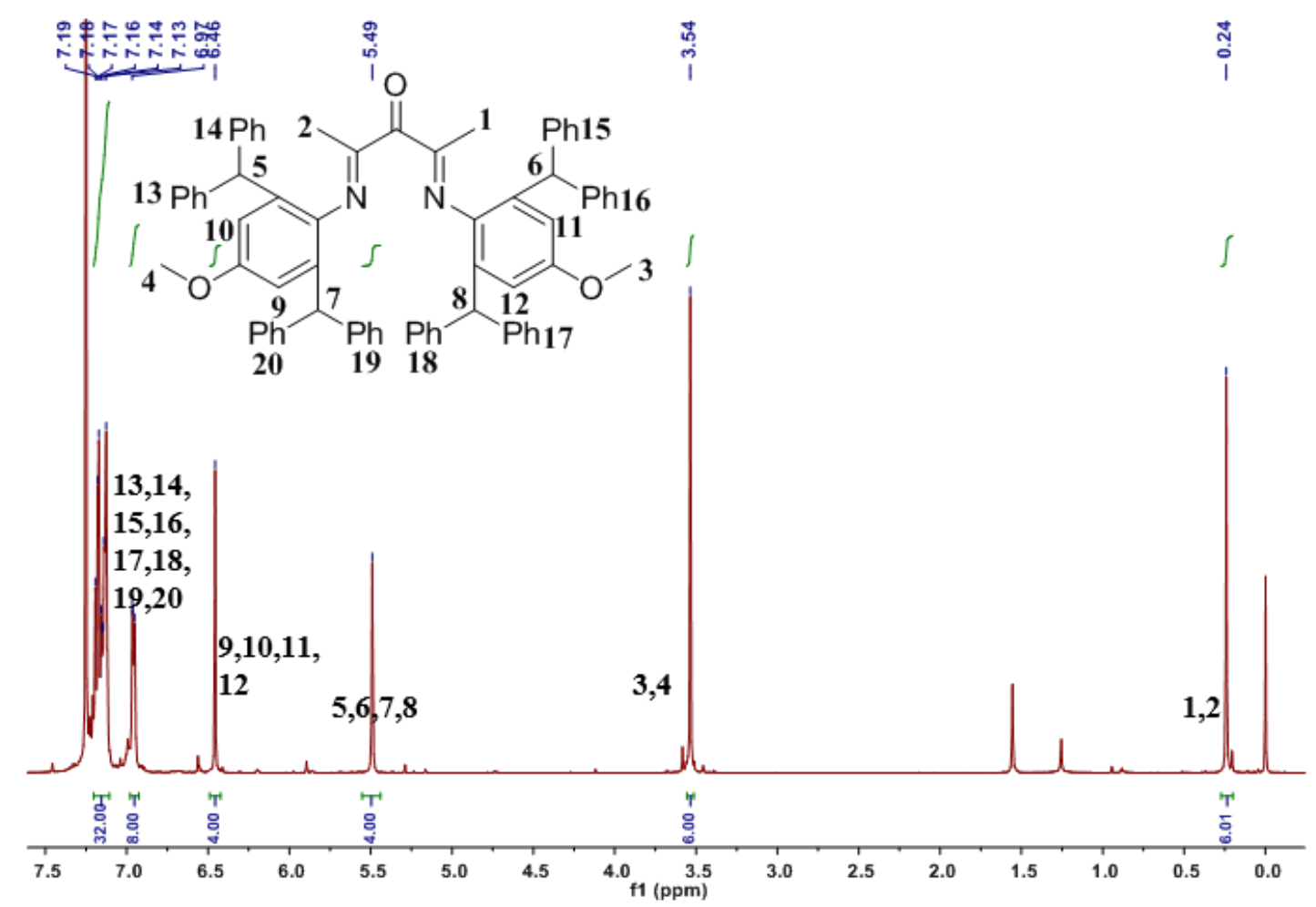

Figure S4. ${ }^{1} \mathrm{H}$ NMR spectrum of $\mathbf{L} 3$ in $\mathrm{CDCl}_{3}$. 

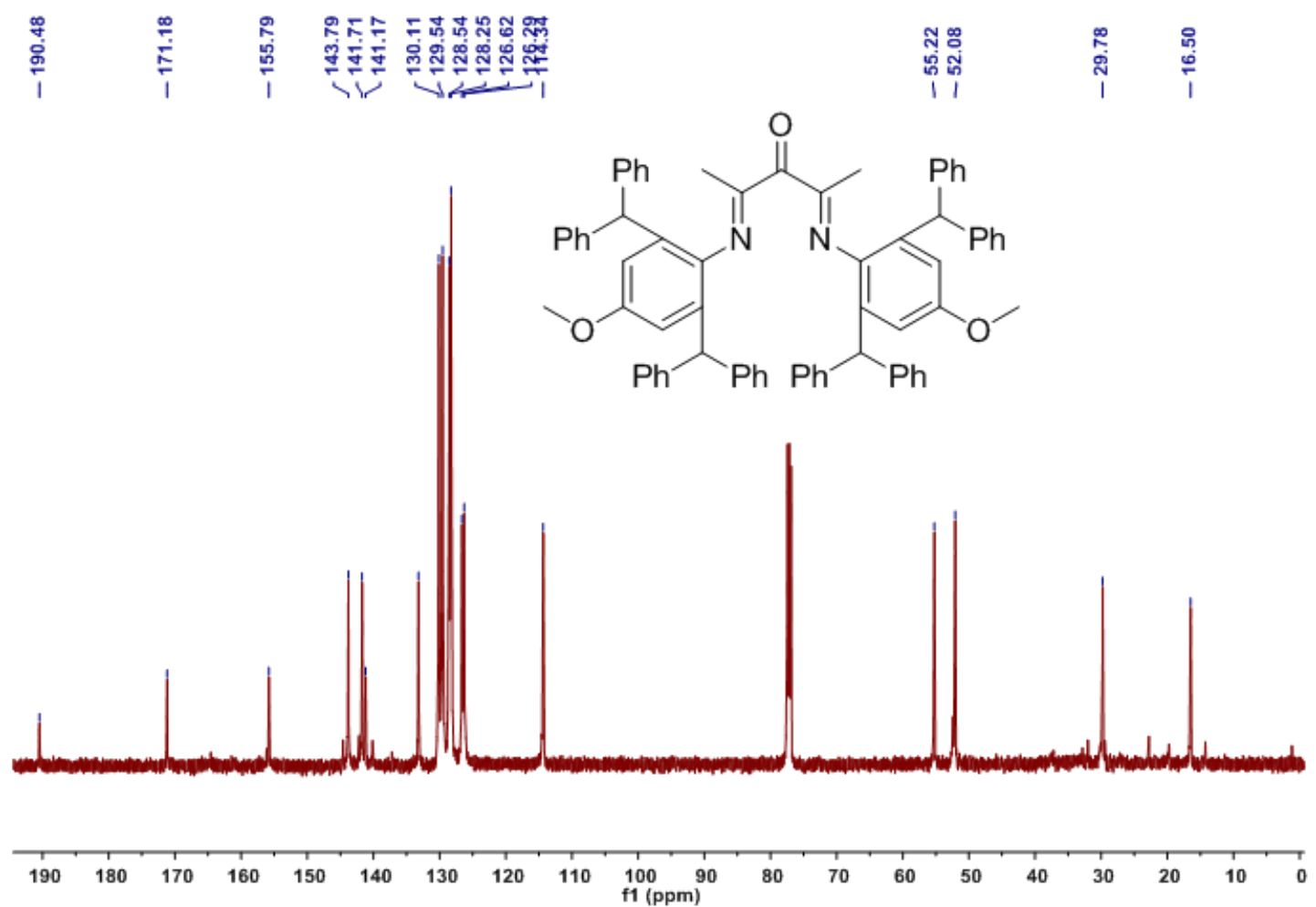

Figure S5. ${ }^{13} \mathrm{C}$ NMR spectrum of $\mathbf{L 3}$ in $\mathrm{CDCl}_{3}$.

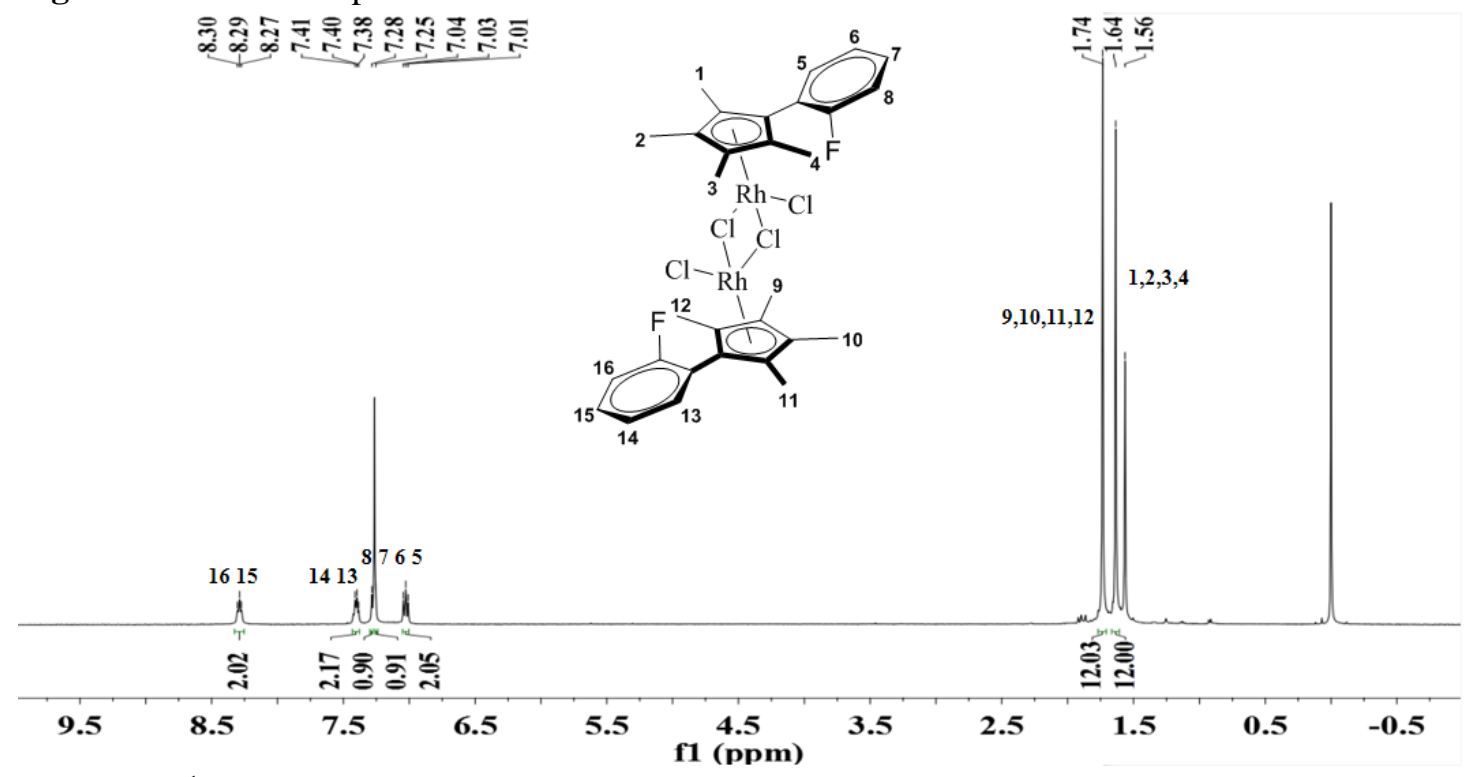

Figure S6. ${ }^{1} \mathrm{H}$ NMR spectrum of $\mathbf{D 3}$ in $\mathrm{CDCl}_{3}$. 


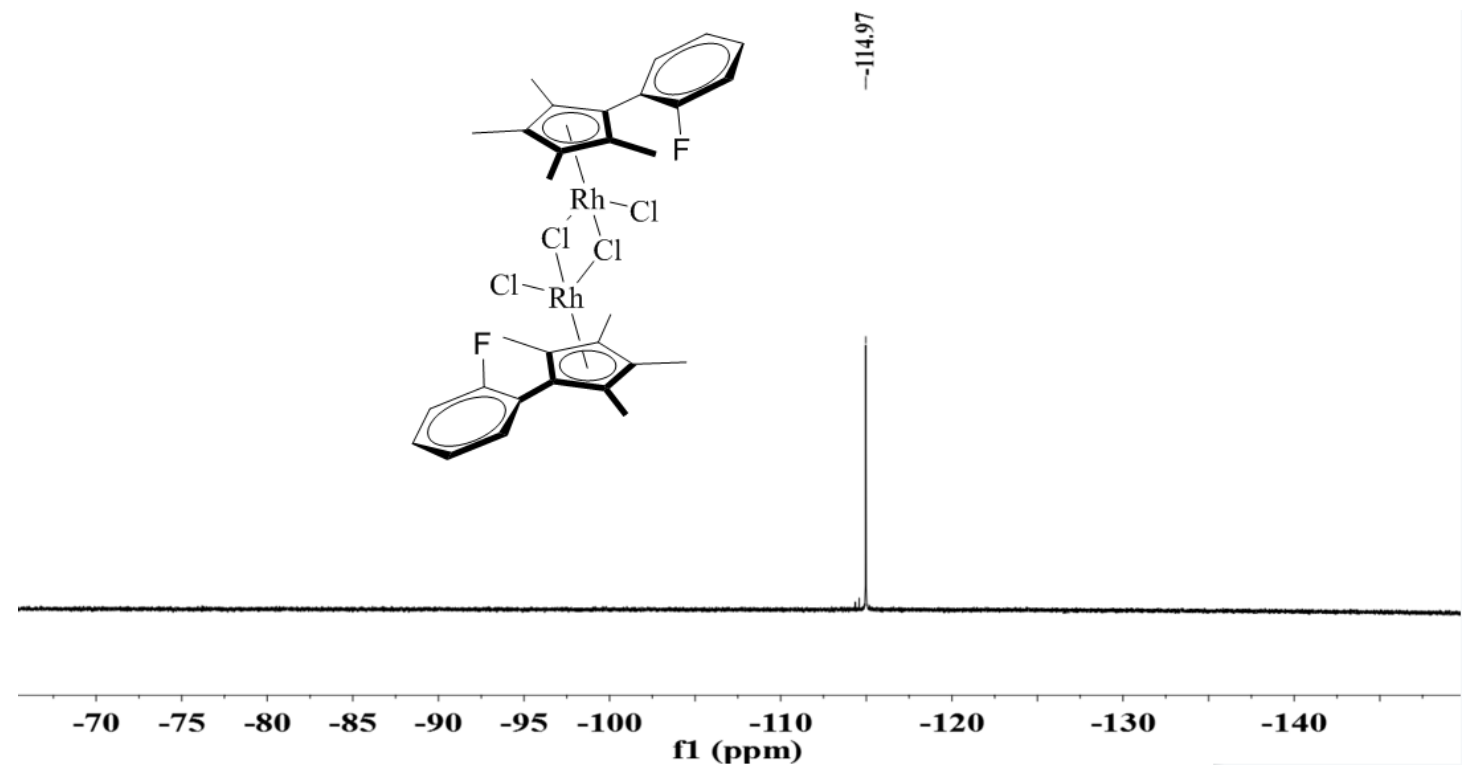

Figure S7. ${ }^{19} \mathrm{~F}$ NMR spectrum of $\mathbf{D 3}$ in $\mathrm{CDCl}_{3}$.

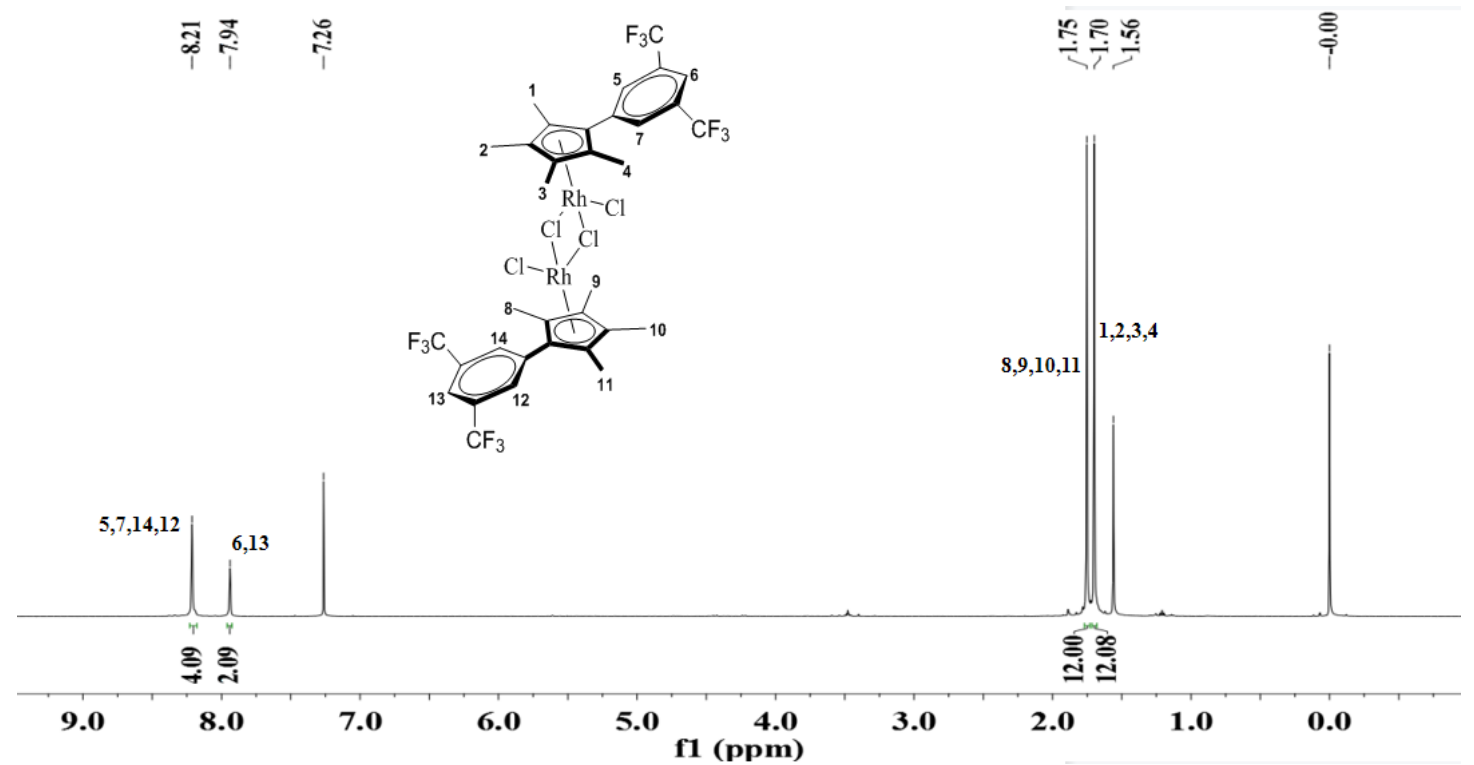

Figure S8. ${ }^{1} \mathrm{H}$ NMR spectrum of $\mathbf{D 4}$ in $\mathrm{CDCl}_{3}$. 


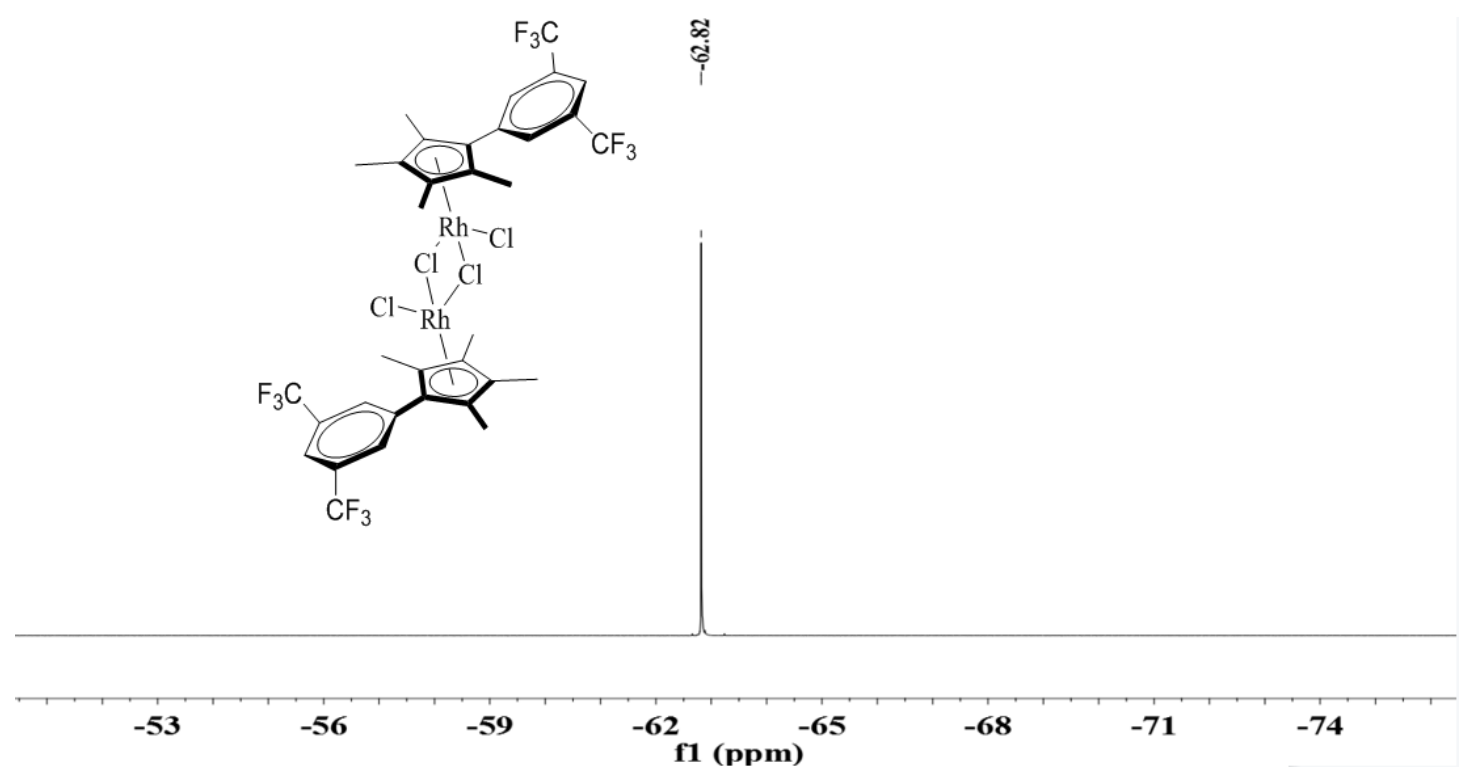

Figure S9. ${ }^{19} \mathrm{~F}$ NMR spectrum of $\mathbf{D 4}$ in $\mathrm{CDCl}_{3}$.

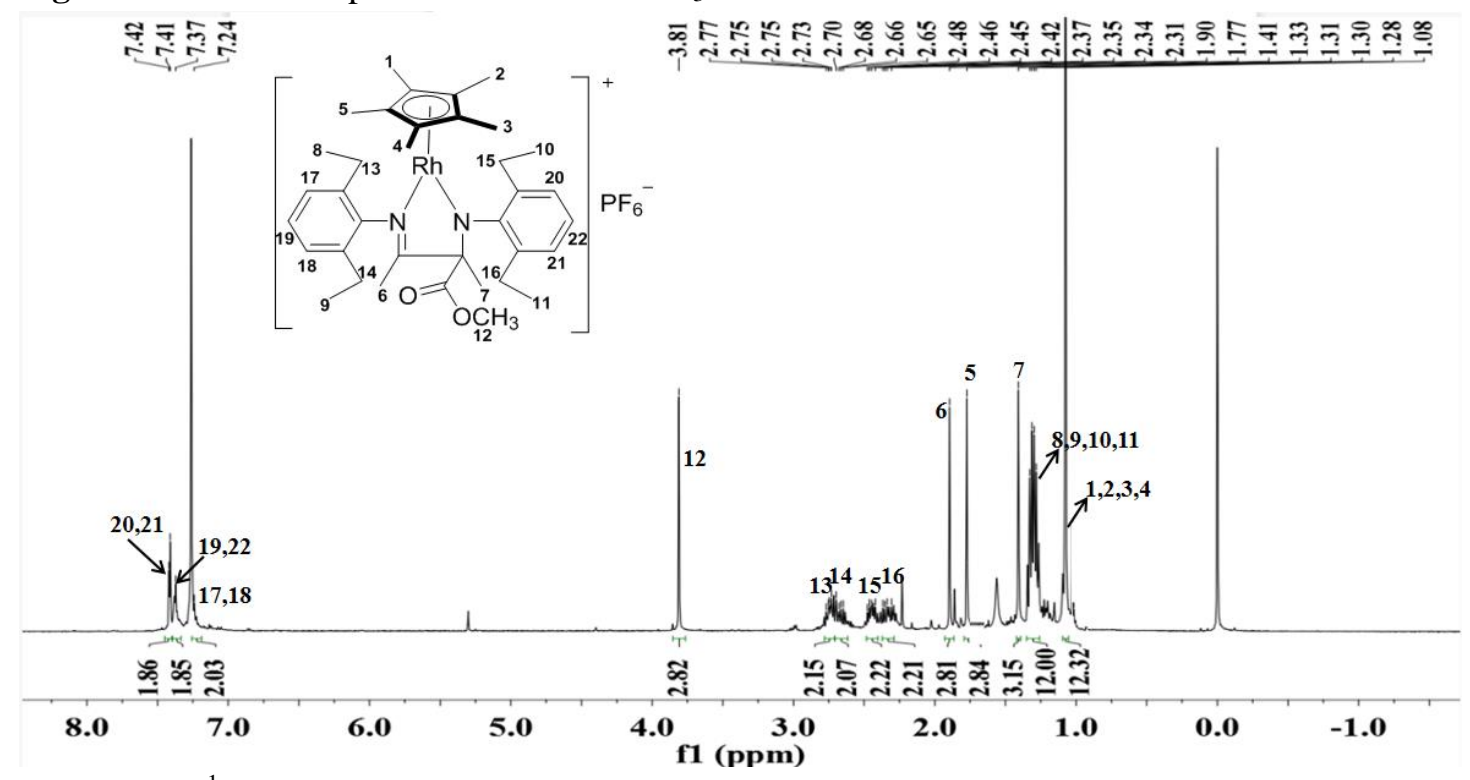

Figure S10. ${ }^{1} \mathrm{H}$ NMR spectrum of $\mathbf{R h 1}$ in $\mathrm{CDCl}_{3}$. 


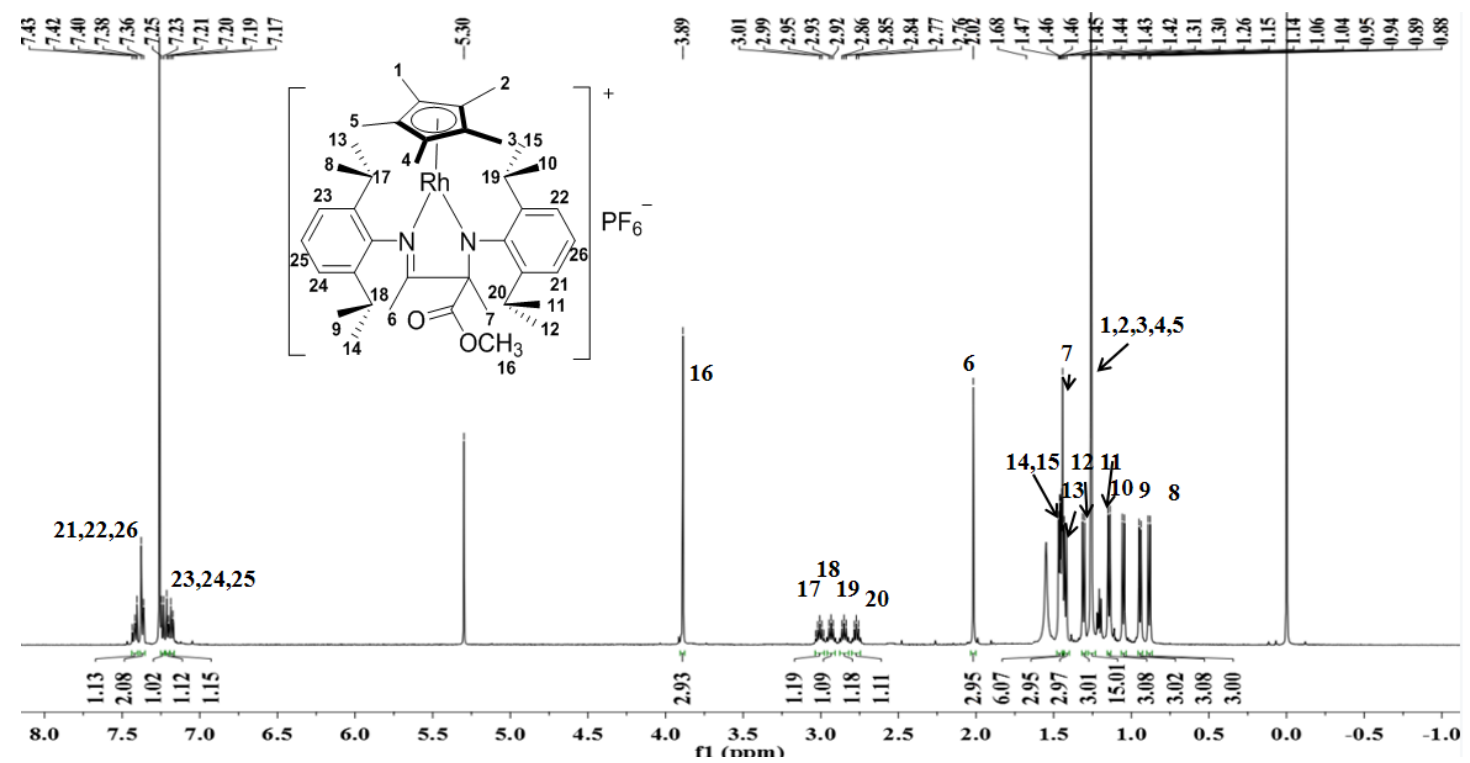

Figure S11. ${ }^{1} \mathrm{H}$ NMR spectrum of $\mathbf{R h} 2$ in $\mathrm{CDCl}_{3}$.

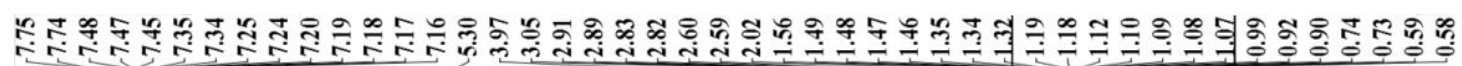

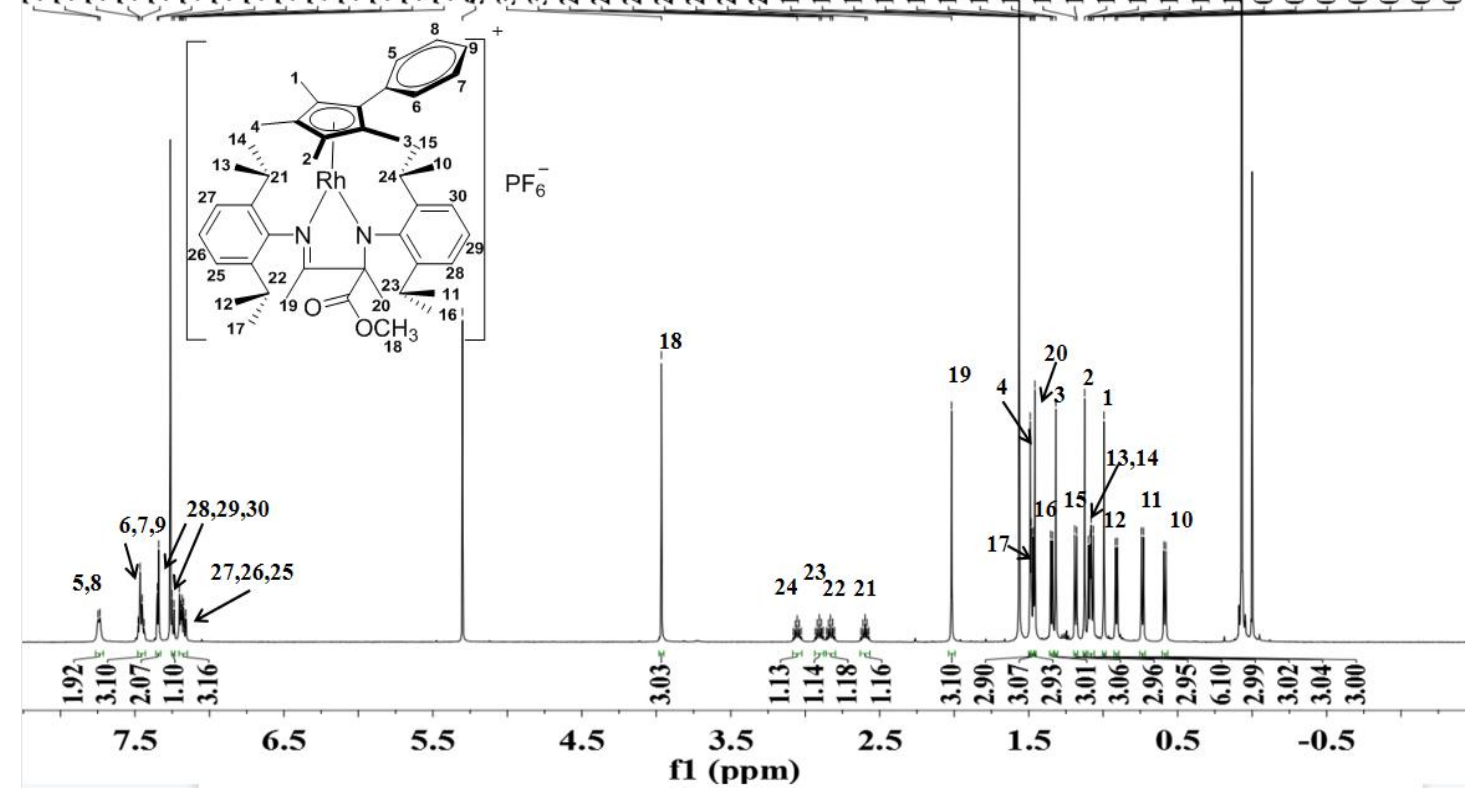

Figure S12. ${ }^{1} \mathrm{H}$ NMR spectrum of $\mathbf{R h} \mathbf{3}$ in $\mathrm{CDCl}_{3}$. 


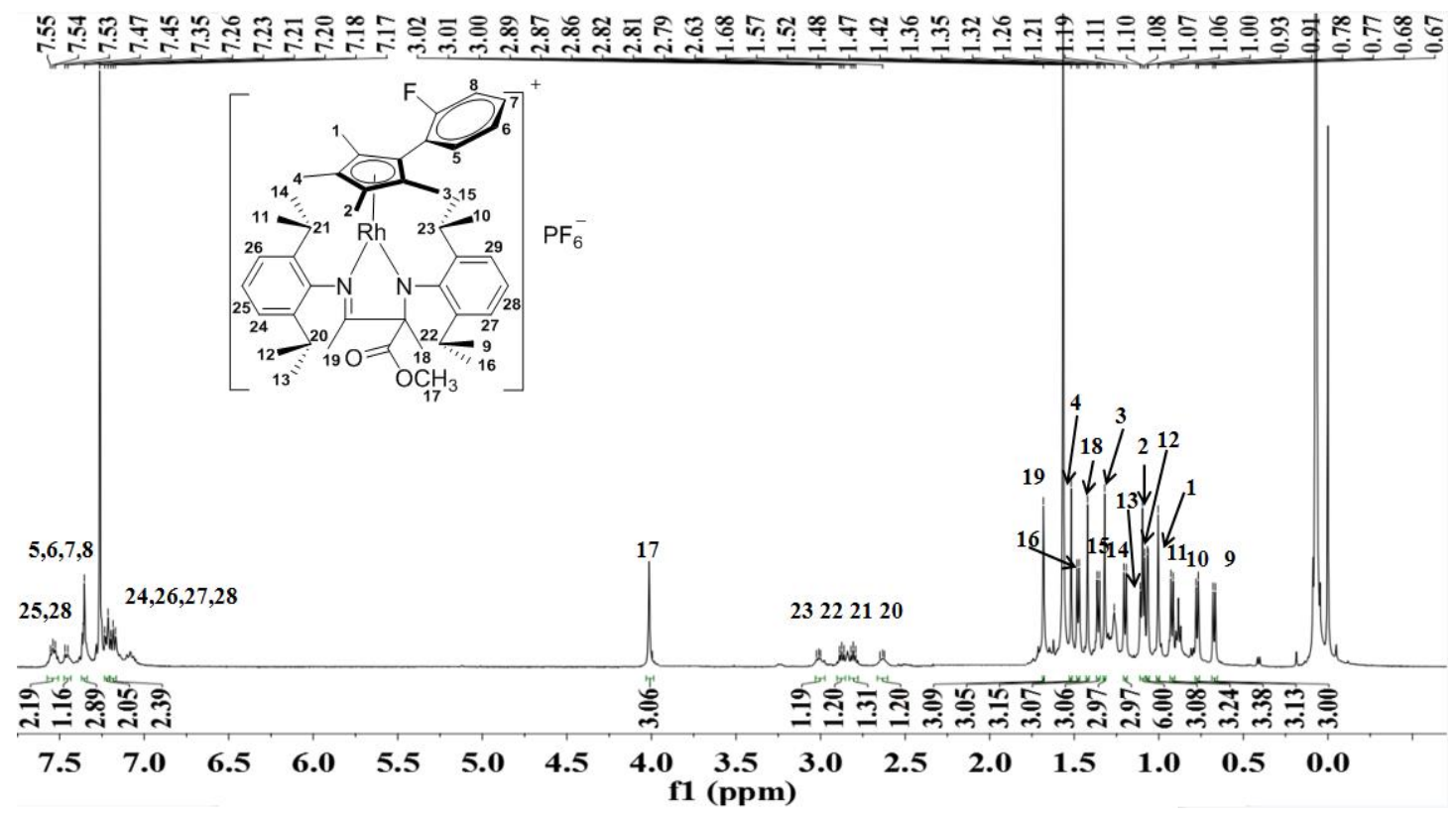

Figure S13. ${ }^{1} \mathrm{H}$ NMR spectrum of $\mathbf{R h} 4$ in $\mathrm{CDCl}_{3}$.

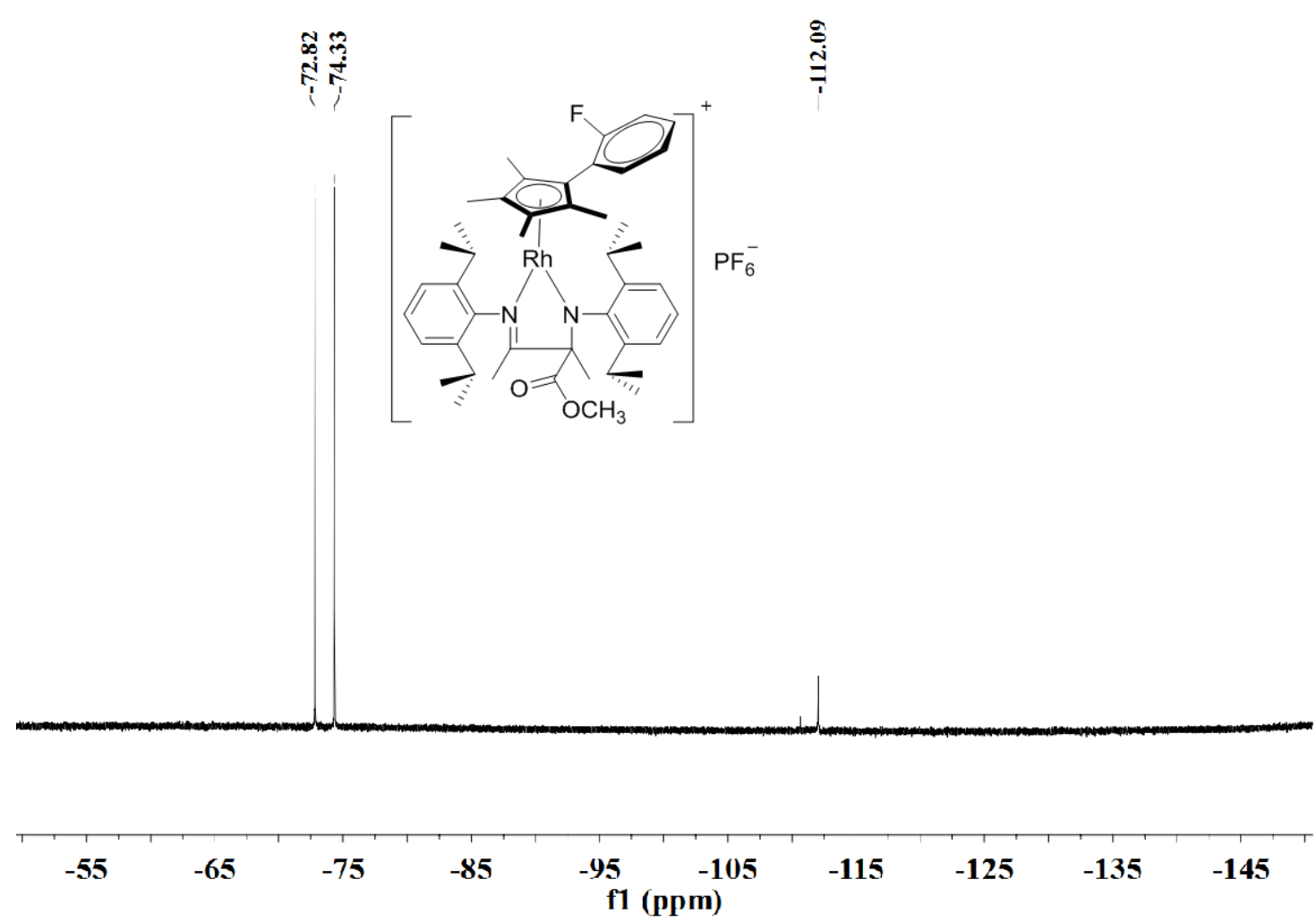

Figure S14. ${ }^{19} \mathrm{~F}$ NMR spectrum of $\mathbf{R h} 4$ in $\mathrm{CDCl}_{3}$. 


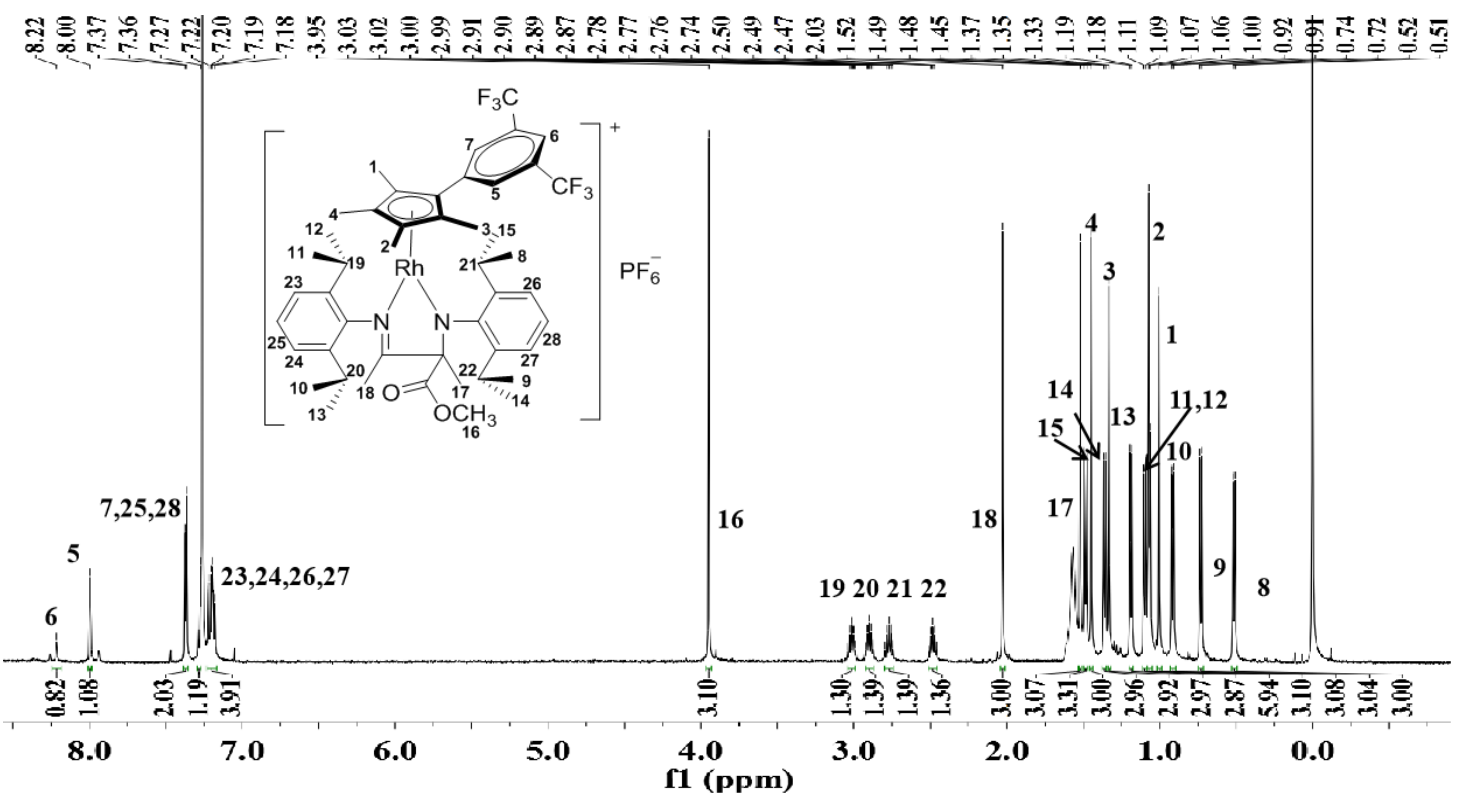

Figure S15. ${ }^{1} \mathrm{H}$ NMR spectrum of $\mathbf{R h 5}$ in $\mathrm{CDCl}_{3}$.

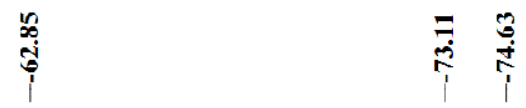
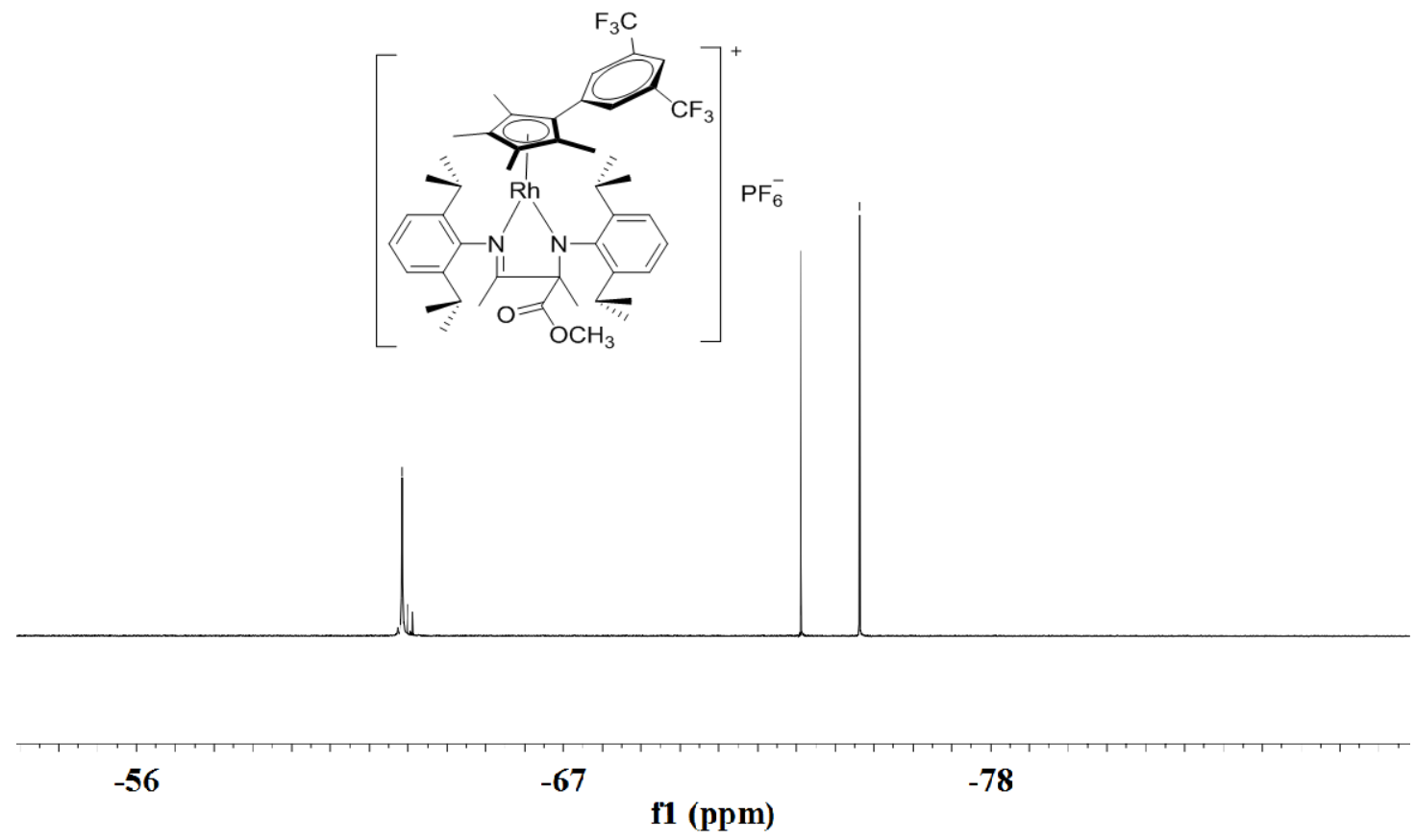

Figure S16. ${ }^{19} \mathrm{~F}$ NMR spectrum of $\mathbf{R h} 5$ in $\mathrm{CDCl}_{3}$. 


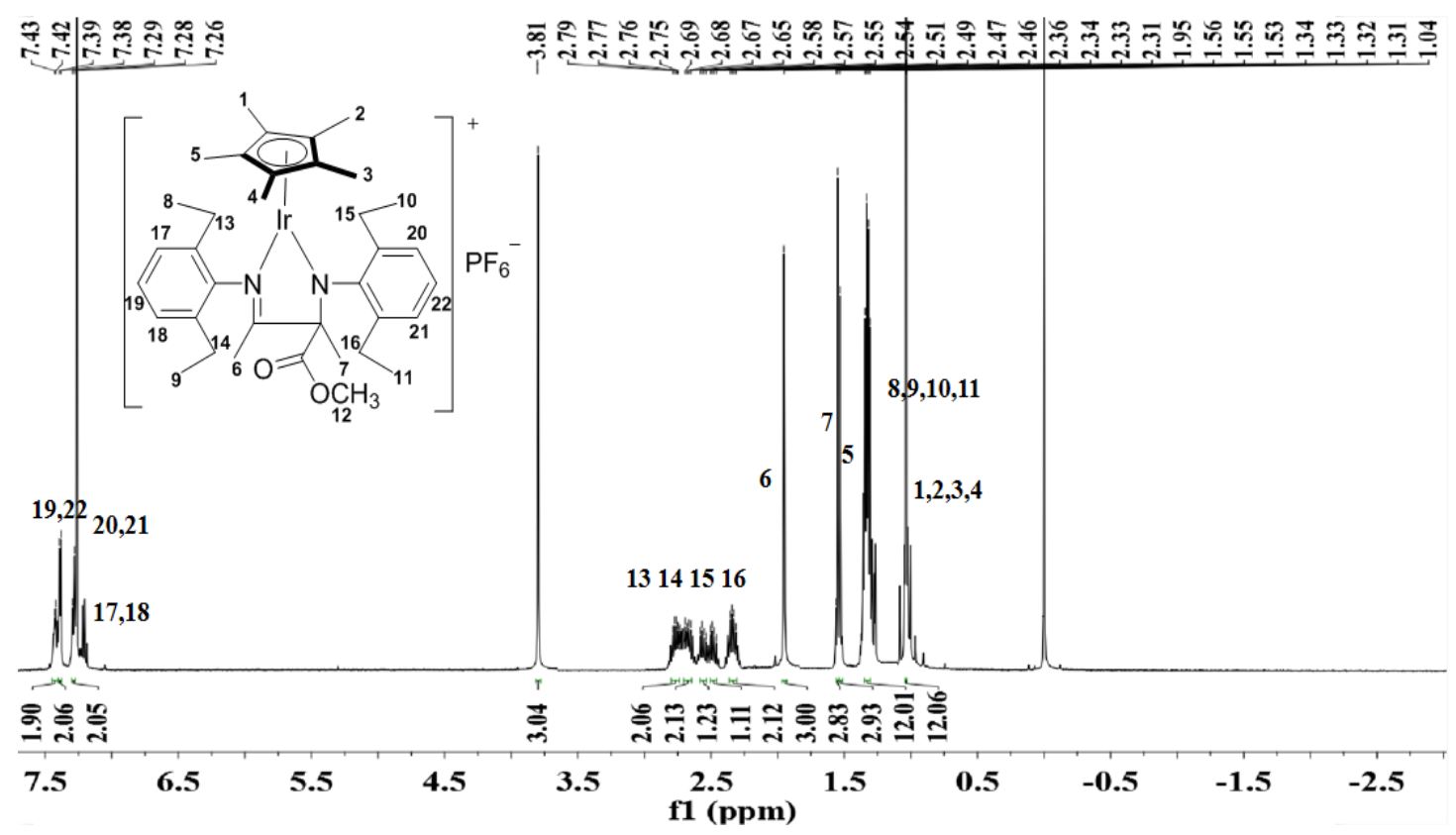

Figure S17. ${ }^{1} \mathrm{H}$ NMR spectrum of $\mathbf{I r} \mathbf{1}$ in $\mathrm{CDCl}_{3}$.

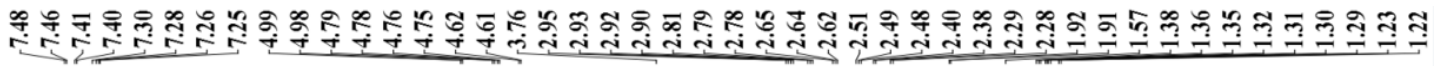

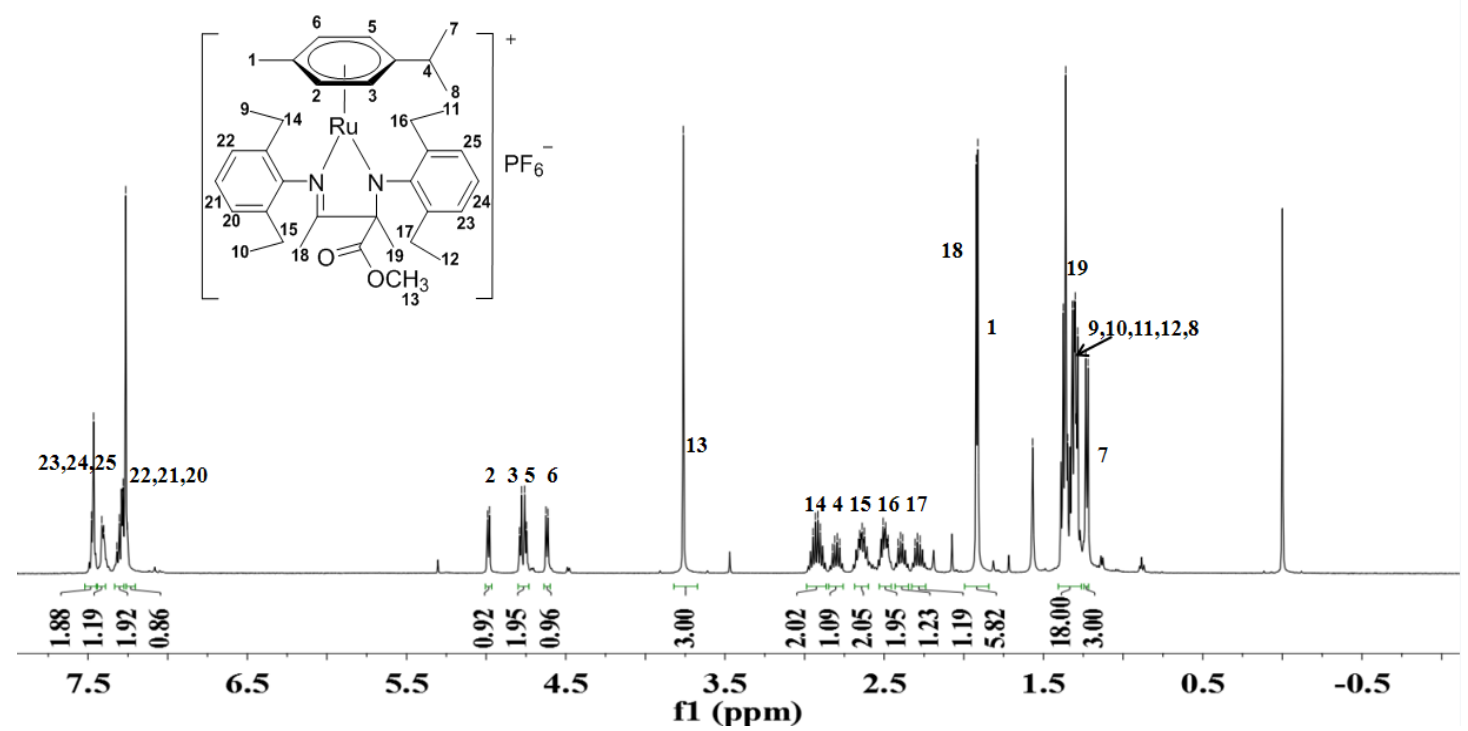

Figure S18. ${ }^{1} \mathrm{H}$ NMR spectrum of $\mathbf{R u 1}$ in $\mathrm{CDCl}_{3}$. 


\section{ESI-MS of L1, L3, D3-D4,Rh1-Rh5, Ir1and Ru1}

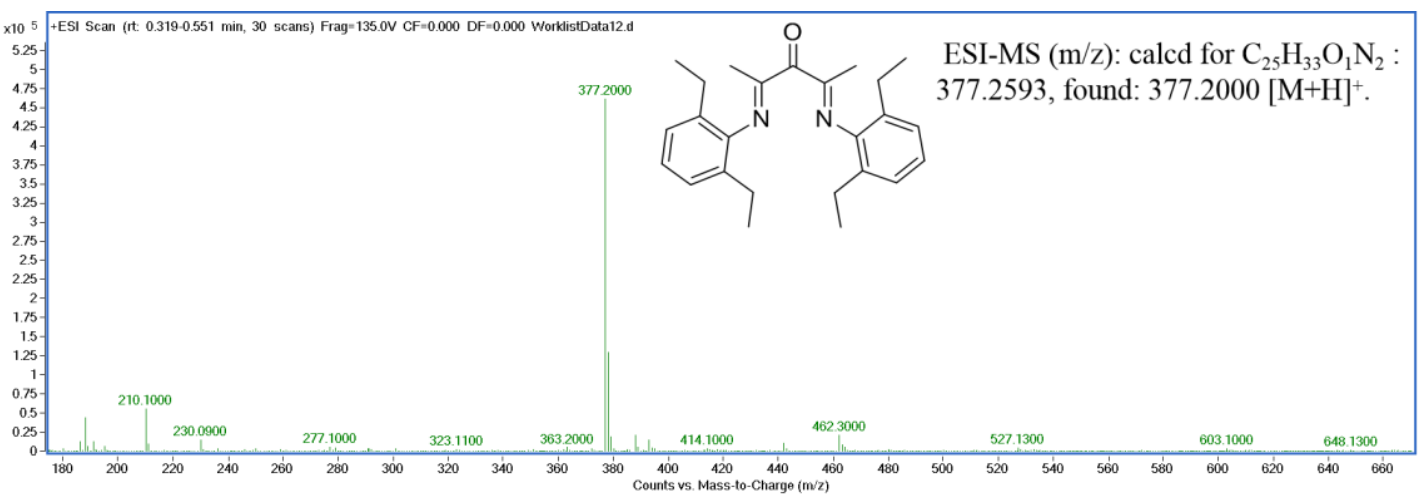

Figure S19. ESI-MS of L1.

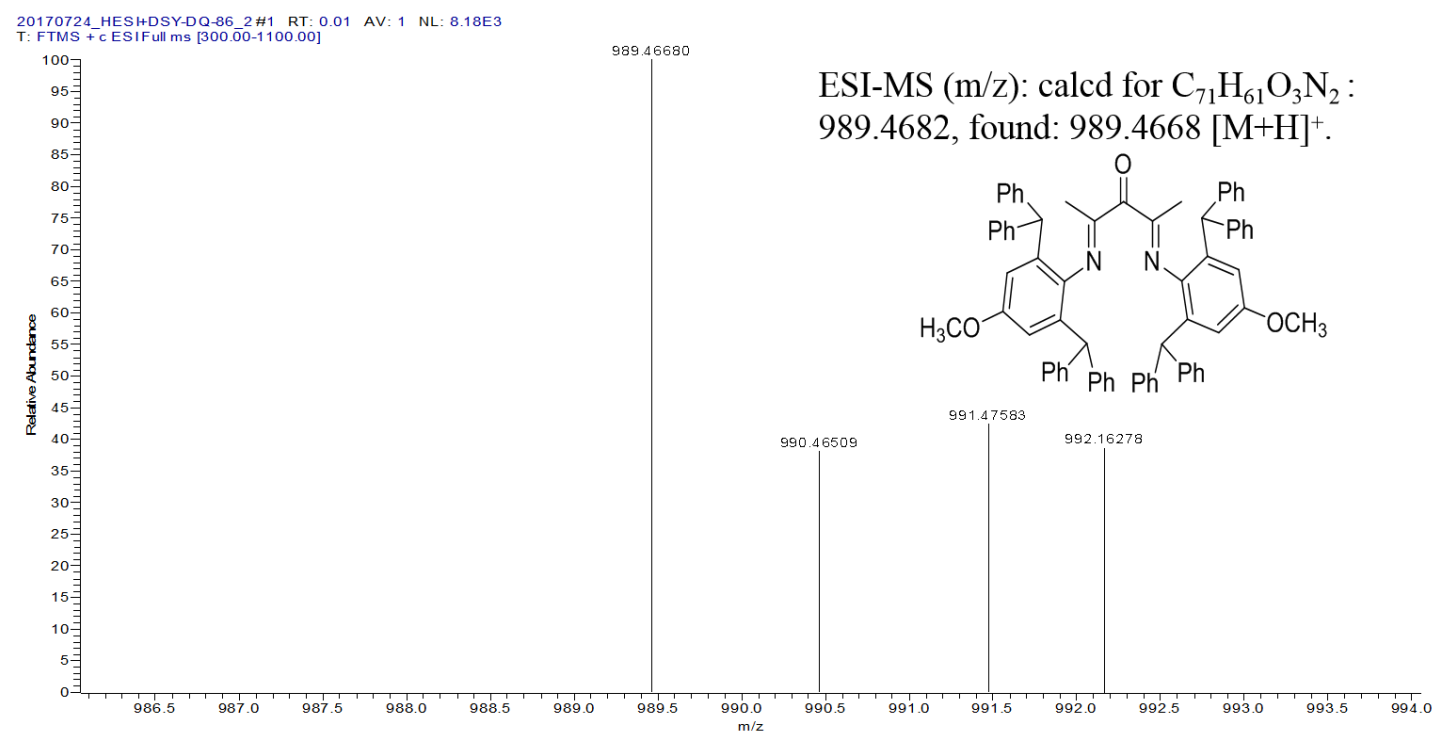

Figure S20. ESI-MS of L3. 


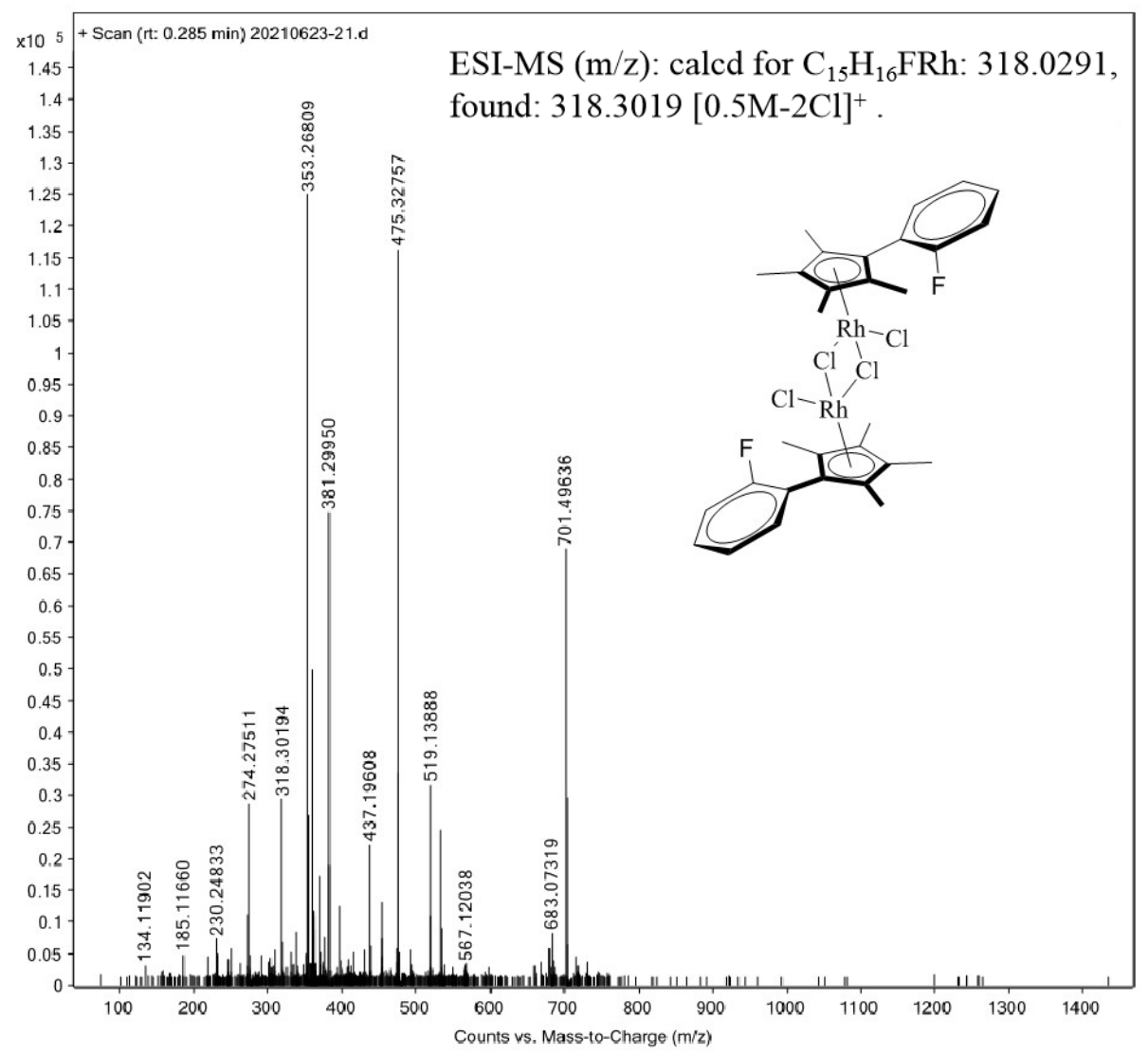

Figure S21. ESI-MS of D3.

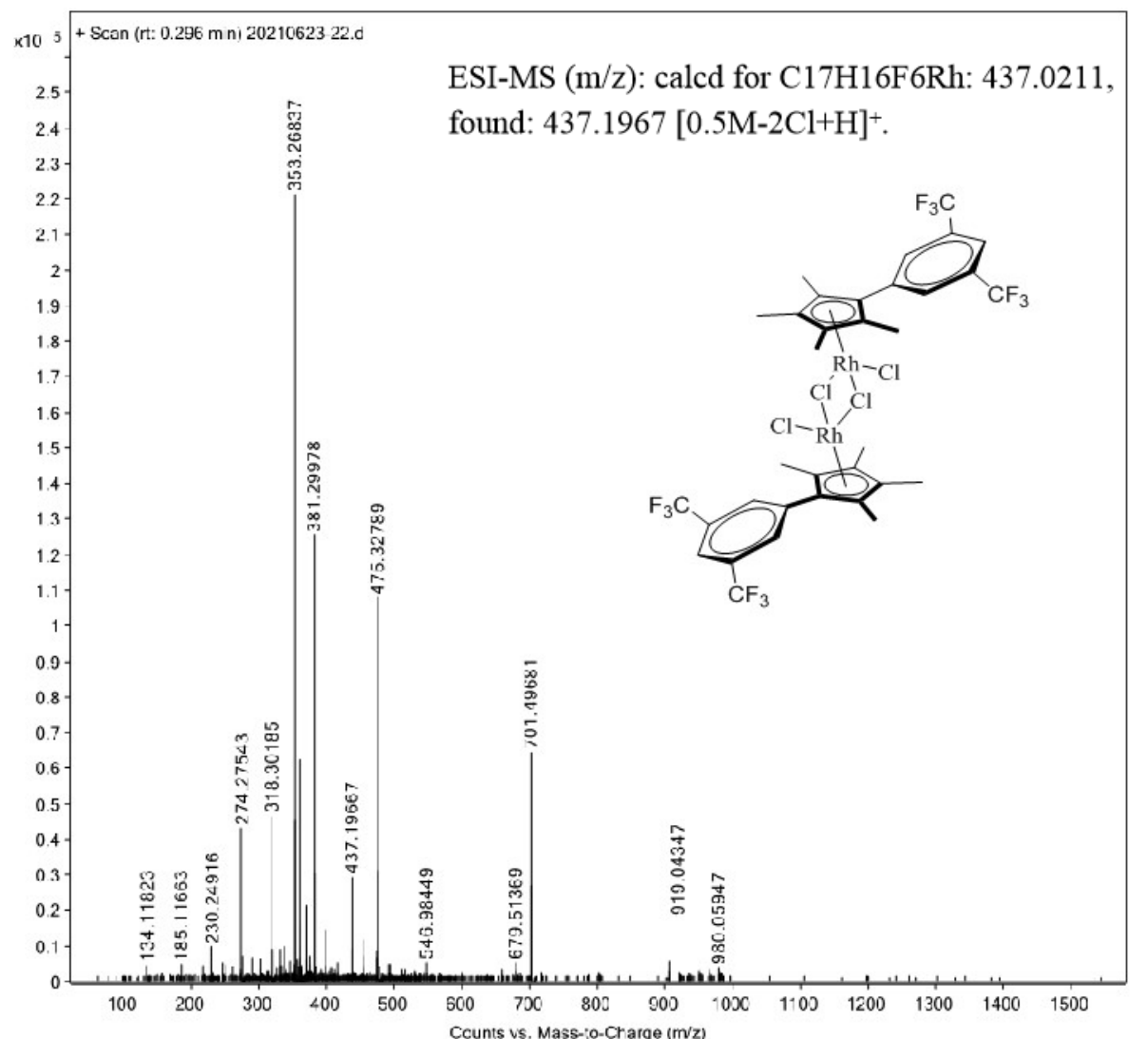

Figure S22. ESI-MS of D4. 


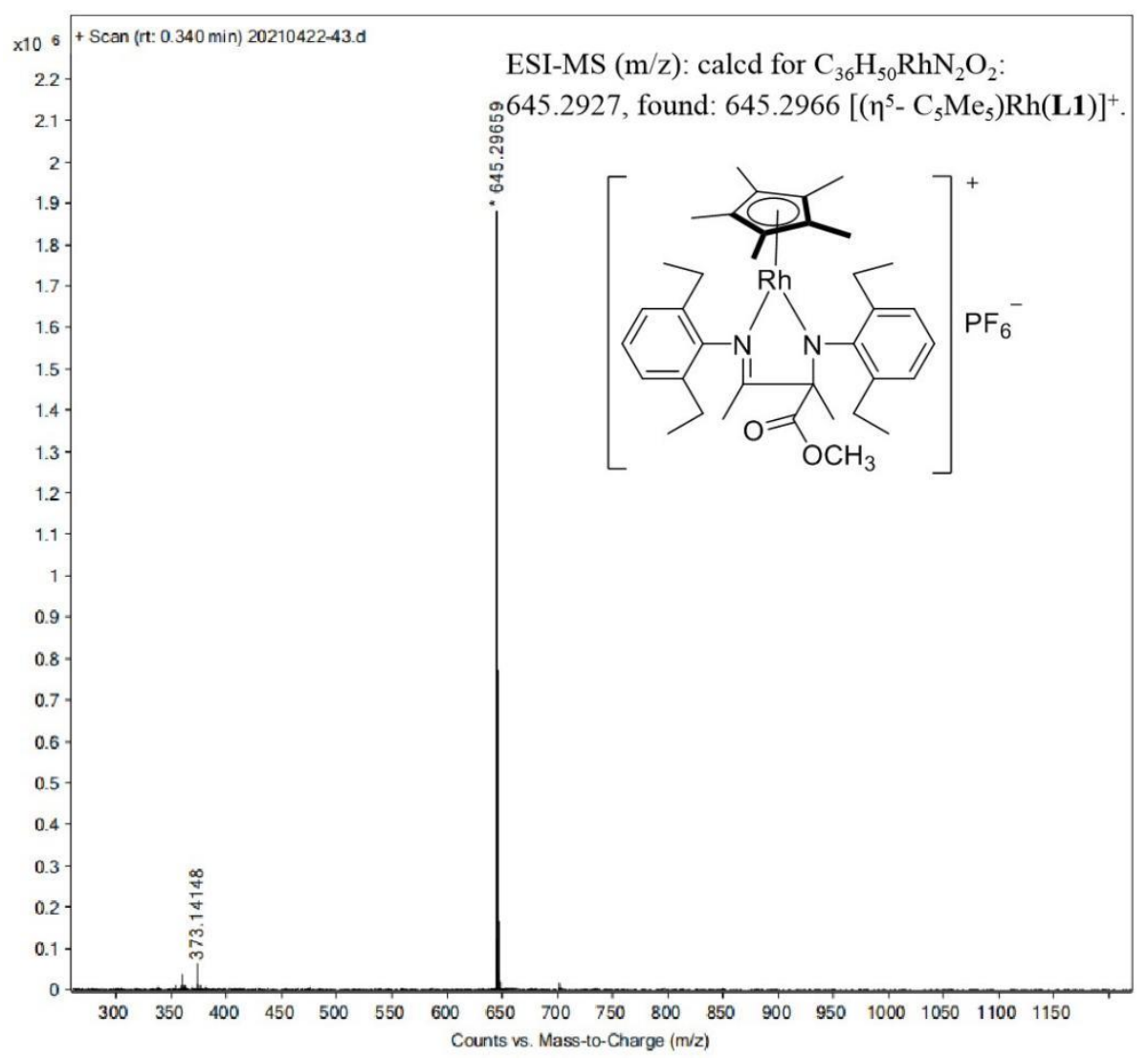

Figure S23. ESI-MS of Rh1.

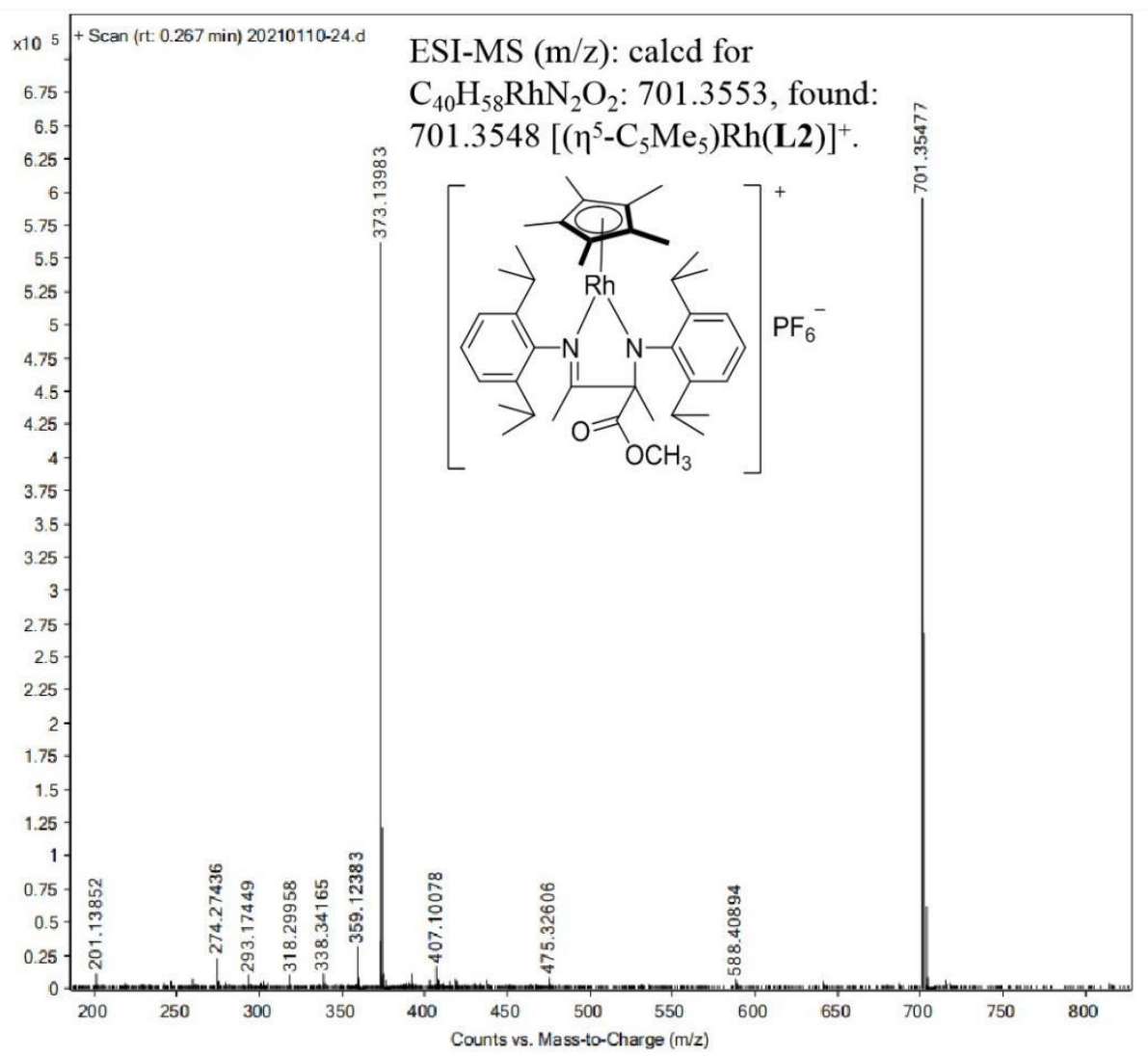

Figure S24. ESI-MS of Rh2. 


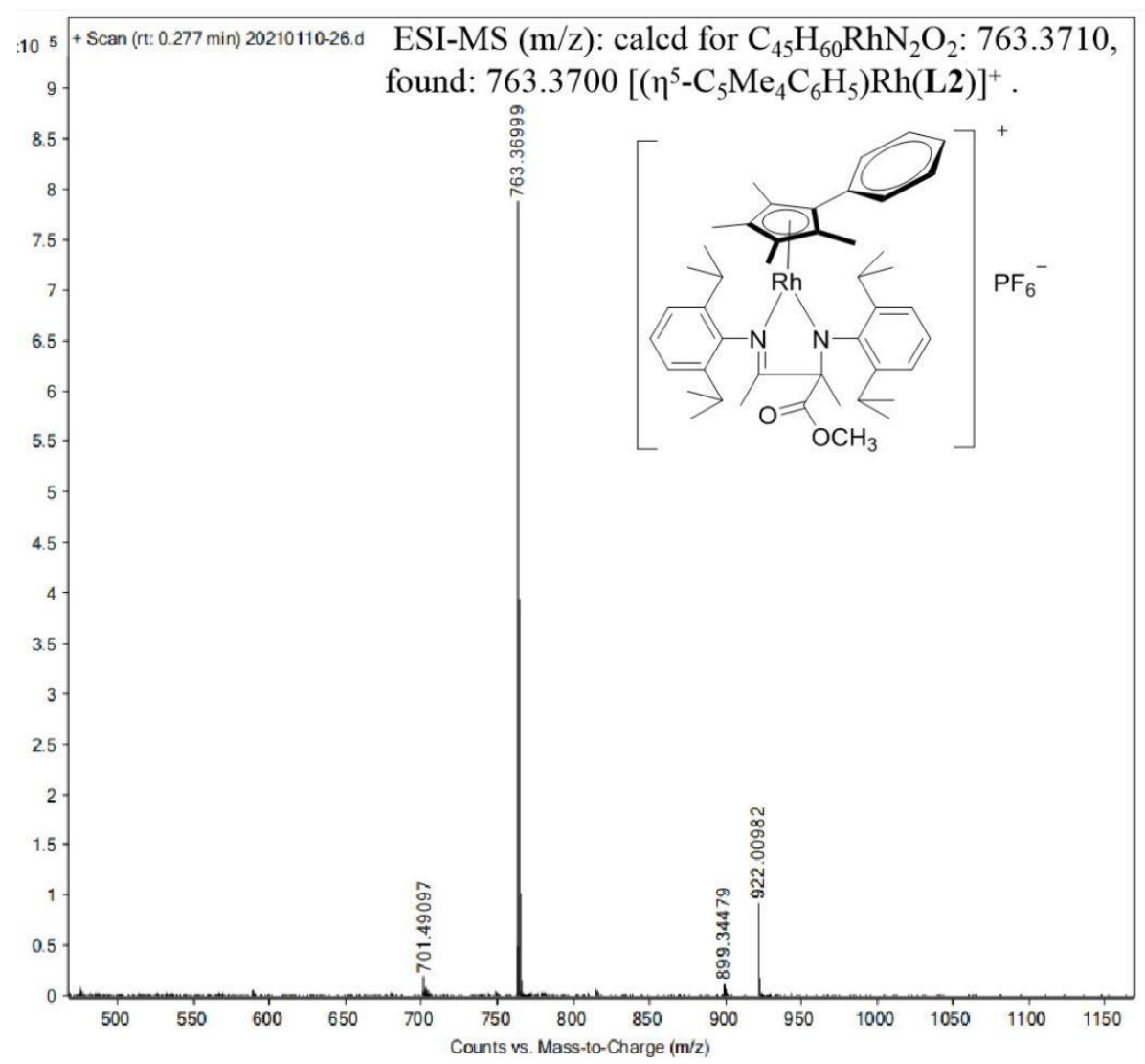

Figure S25. ESI-MS of Rh3.

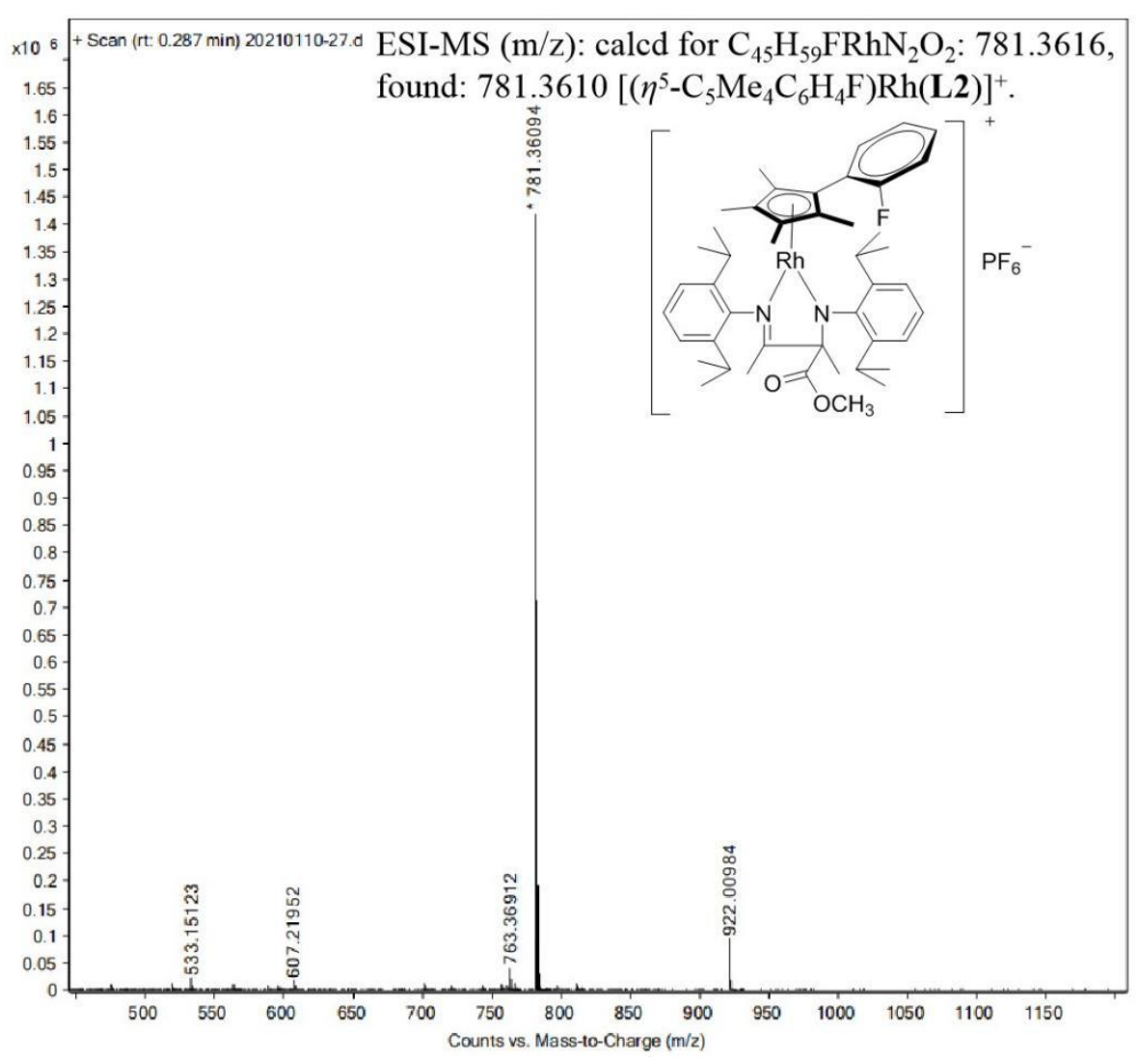

Figure S26. ESI-MS of Rh4. 


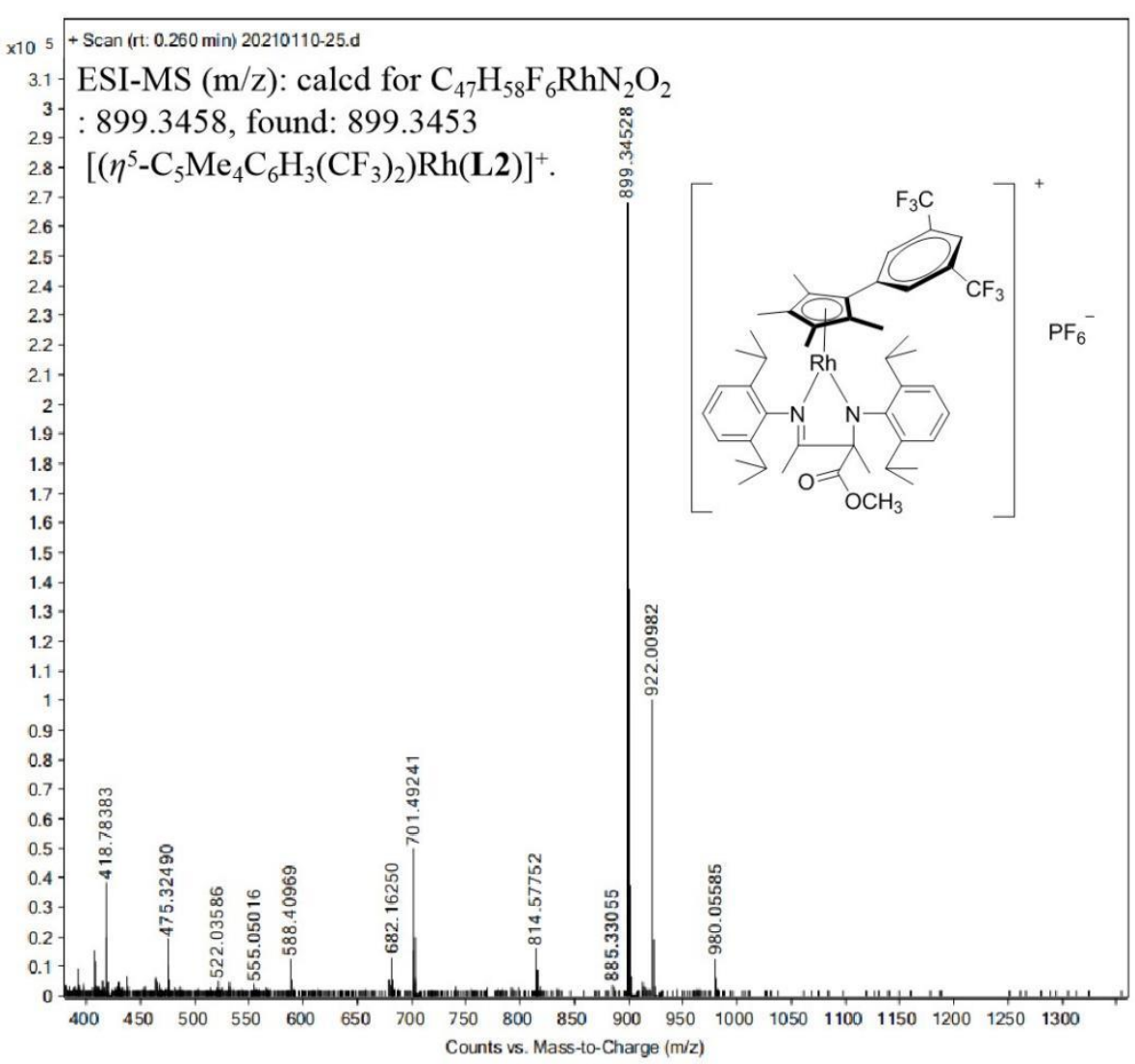

Figure S27. ESI-MS of Rh5.

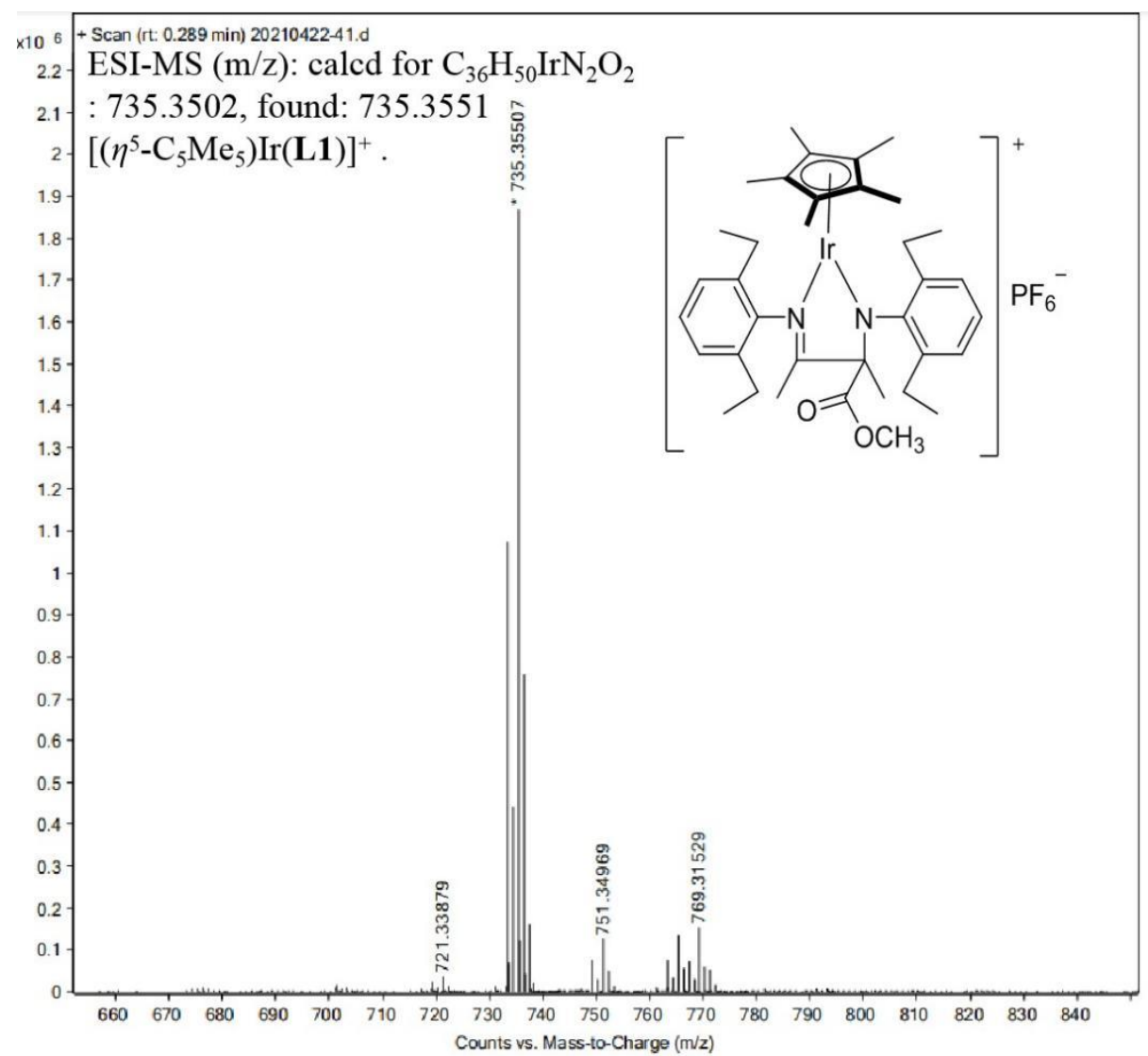

Figure S28. ESI-MS of Ir1. 


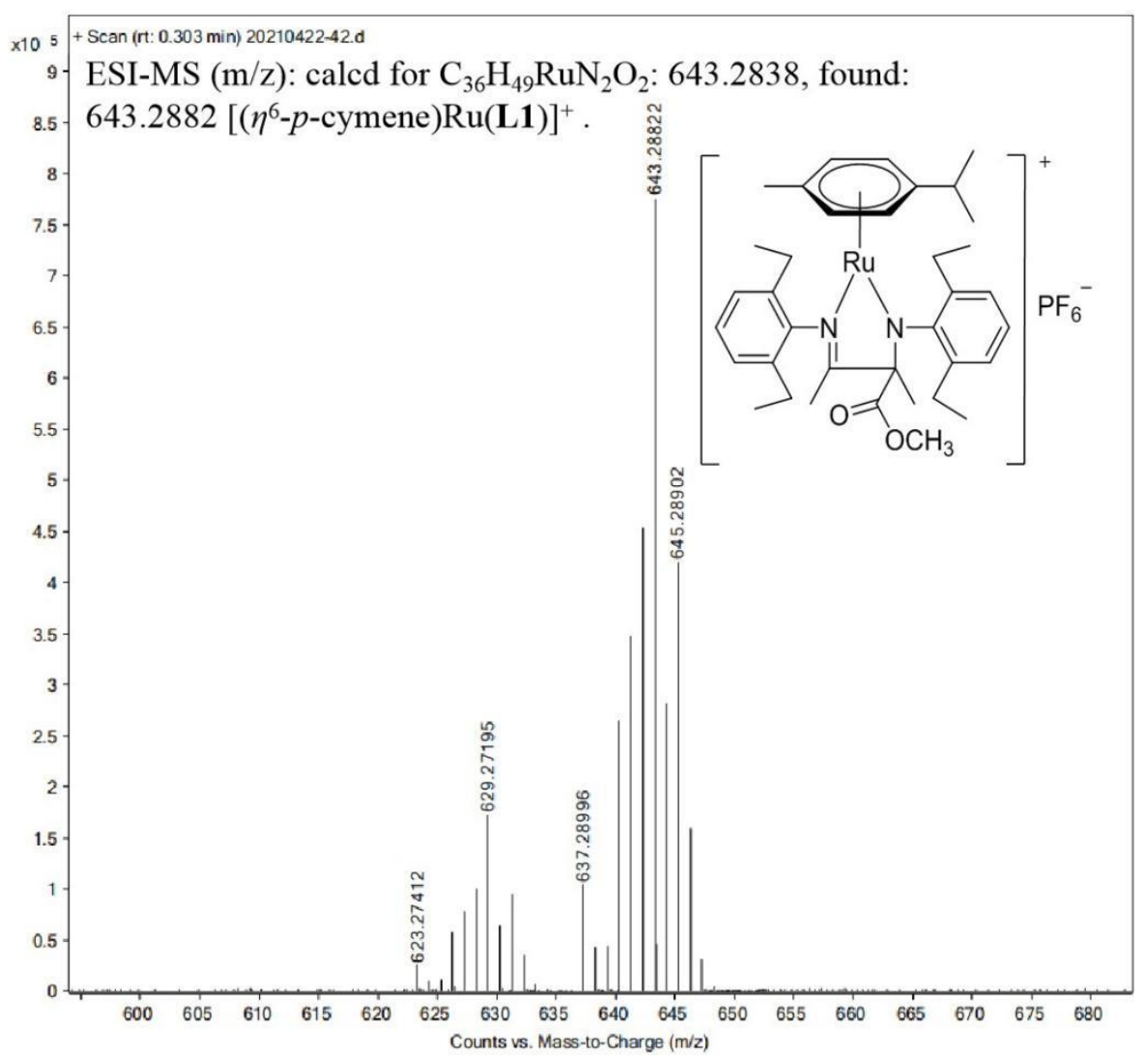

Figure S29. ESI-MS of Ru1.

\section{FIGURE AND TABLE.}

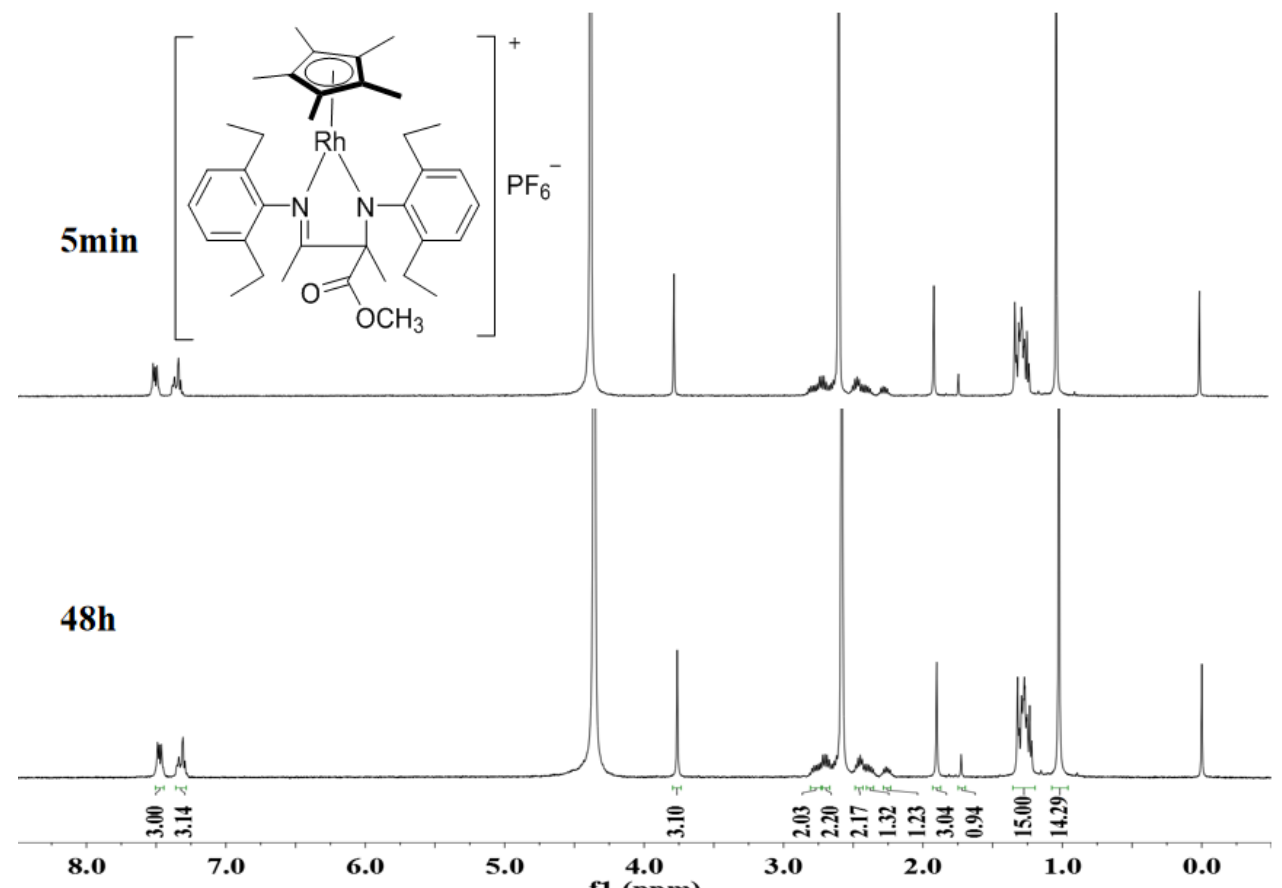

Figure S30. Time-dependent ${ }^{1} \mathrm{H}$ NMR spectroscopic stability study for $\mathbf{R h} \mathbf{1}$ in $75 \%$ DMSO- $d_{6} / 25 \%$ phosphate-buffered saline (PBS) $\left(\mathrm{pH} \approx 7.2\right.$, $\mathrm{PBS}$ is prepared from $\mathrm{D}_{2} \mathrm{O}$ ) over $48 \mathrm{~h}$. 


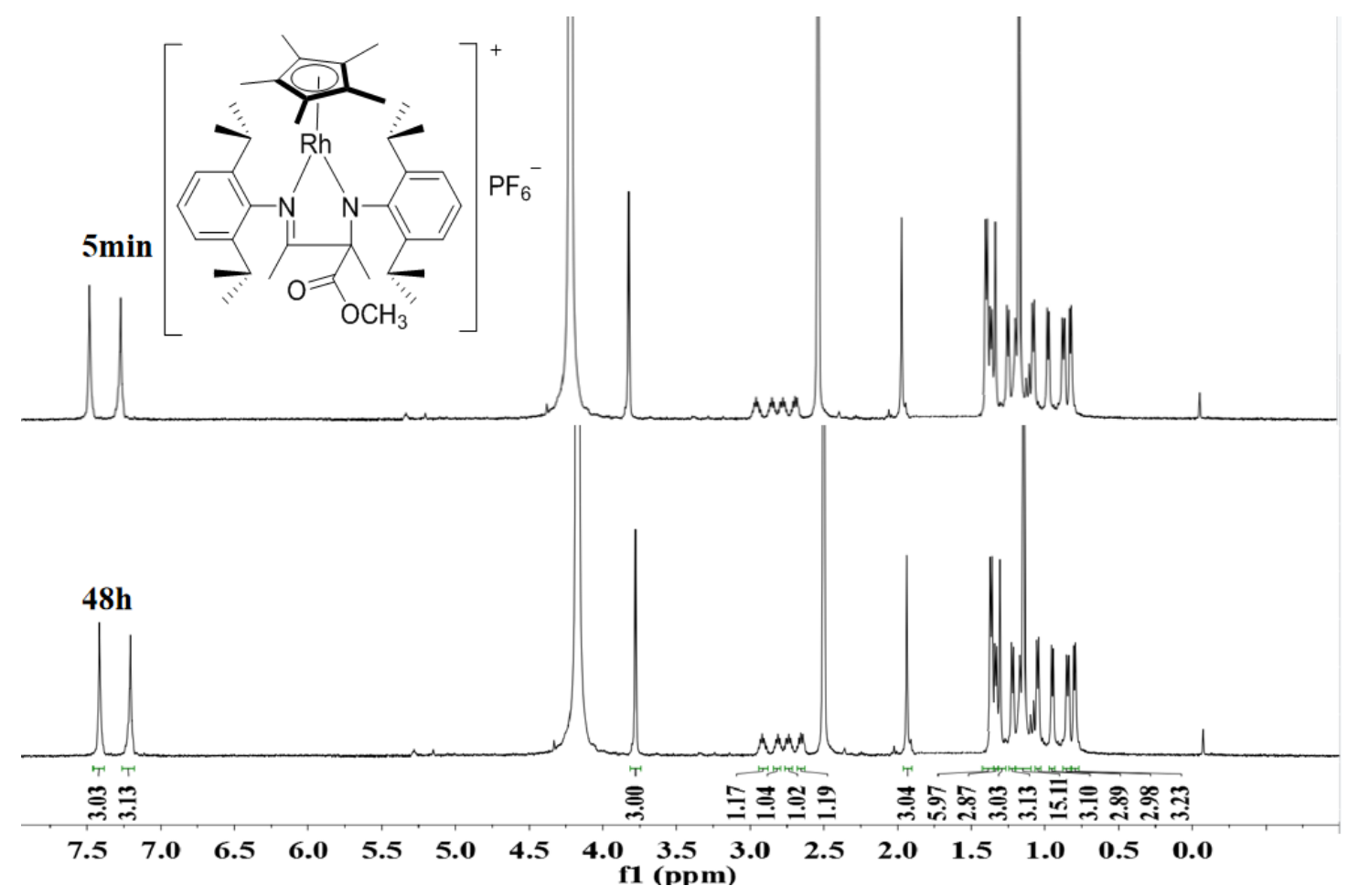

Figure S31. Time-dependent ${ }^{1} \mathrm{H}$ NMR spectroscopic stability study for $\mathbf{R h} \mathbf{2}$ in $75 \%$ DMSO- $d_{6} / 25 \%$ phosphate-buffered saline (PBS) $\left(\mathrm{pH} \approx 7.2\right.$, PBS is prepared from $\mathrm{D}_{2} \mathrm{O}$ ) over $48 \mathrm{~h}$.

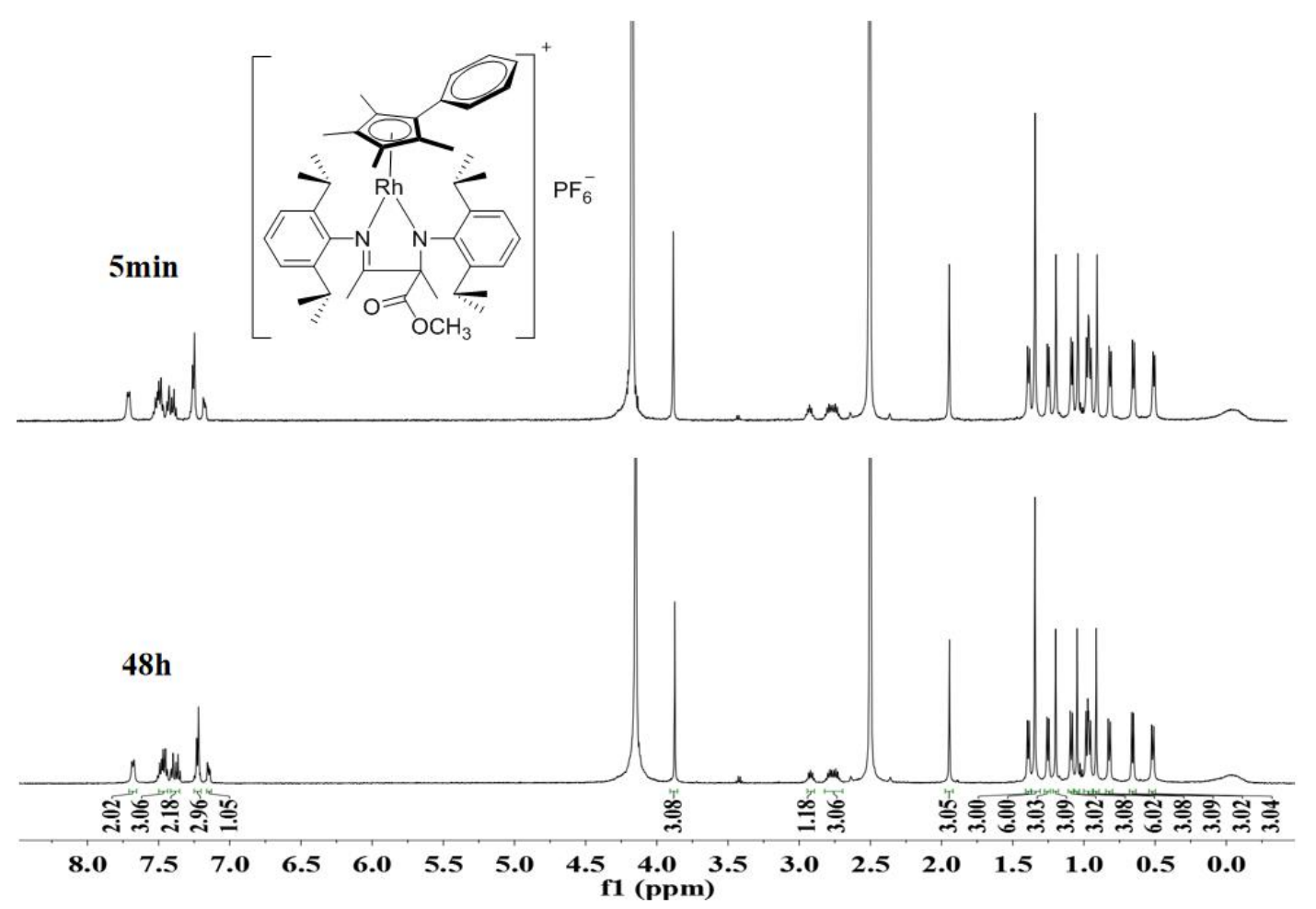

Figure S32. Time-dependent ${ }^{1} \mathrm{H}$ NMR spectroscopic stability study for $\mathbf{R h 3}$ in $75 \%$ DMSO- $d_{6} / 25 \%$ phosphate-buffered saline (PBS) $\left(\mathrm{pH} \approx 7.2\right.$, PBS is prepared from $\mathrm{D}_{2} \mathrm{O}$ ) over $48 \mathrm{~h}$. 


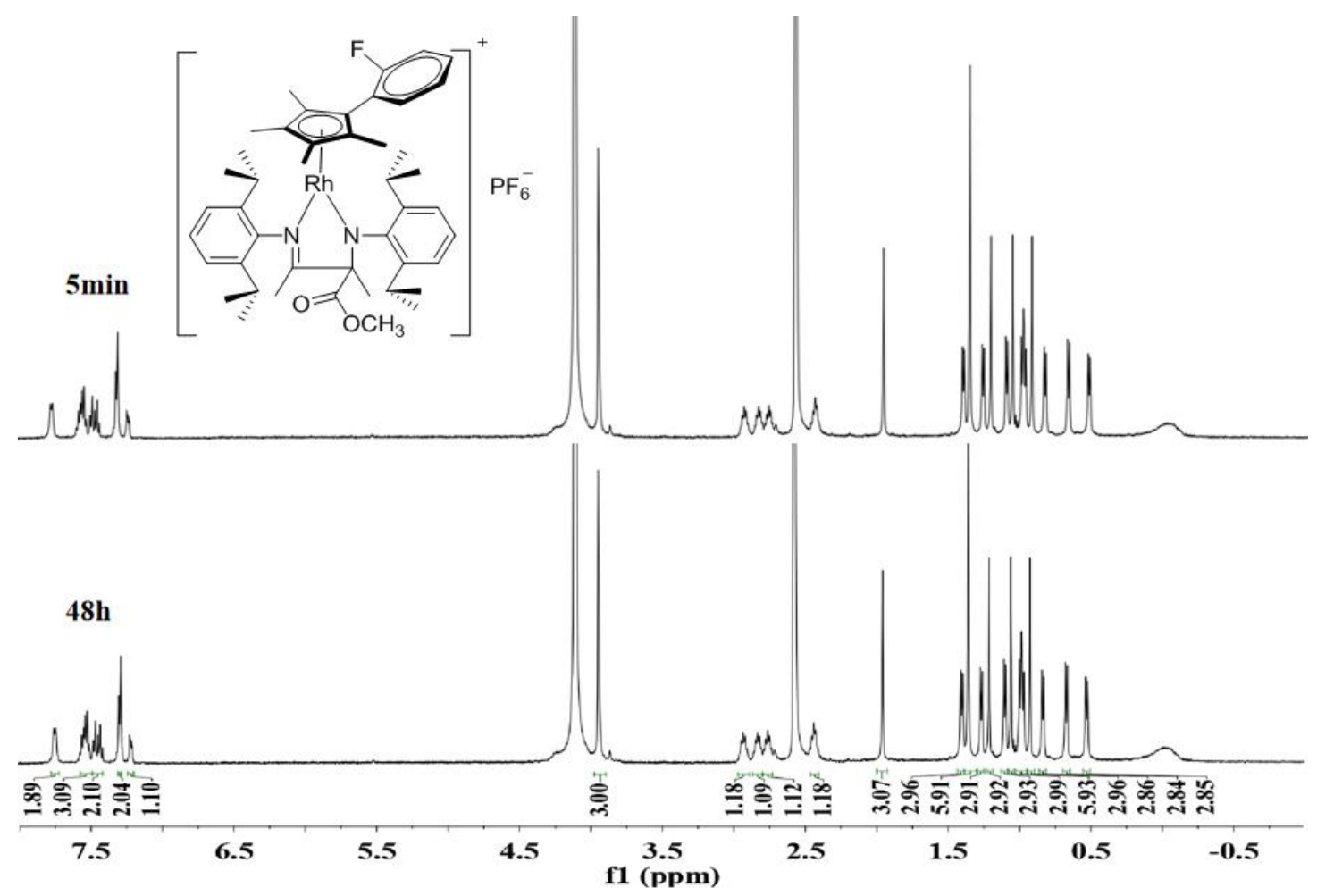

Figure S33. Time-dependent ${ }^{1} \mathrm{H}$ NMR spectroscopic stability study for $\mathbf{R h 4}$ in $75 \%$ DMSO $-d_{6} / 25 \%$ phosphate-buffered saline $(\mathrm{PBS})\left(\mathrm{pH} \approx 7.2\right.$, PBS is prepared from $\mathrm{D}_{2} \mathrm{O}$ ) over $48 \mathrm{~h}$.

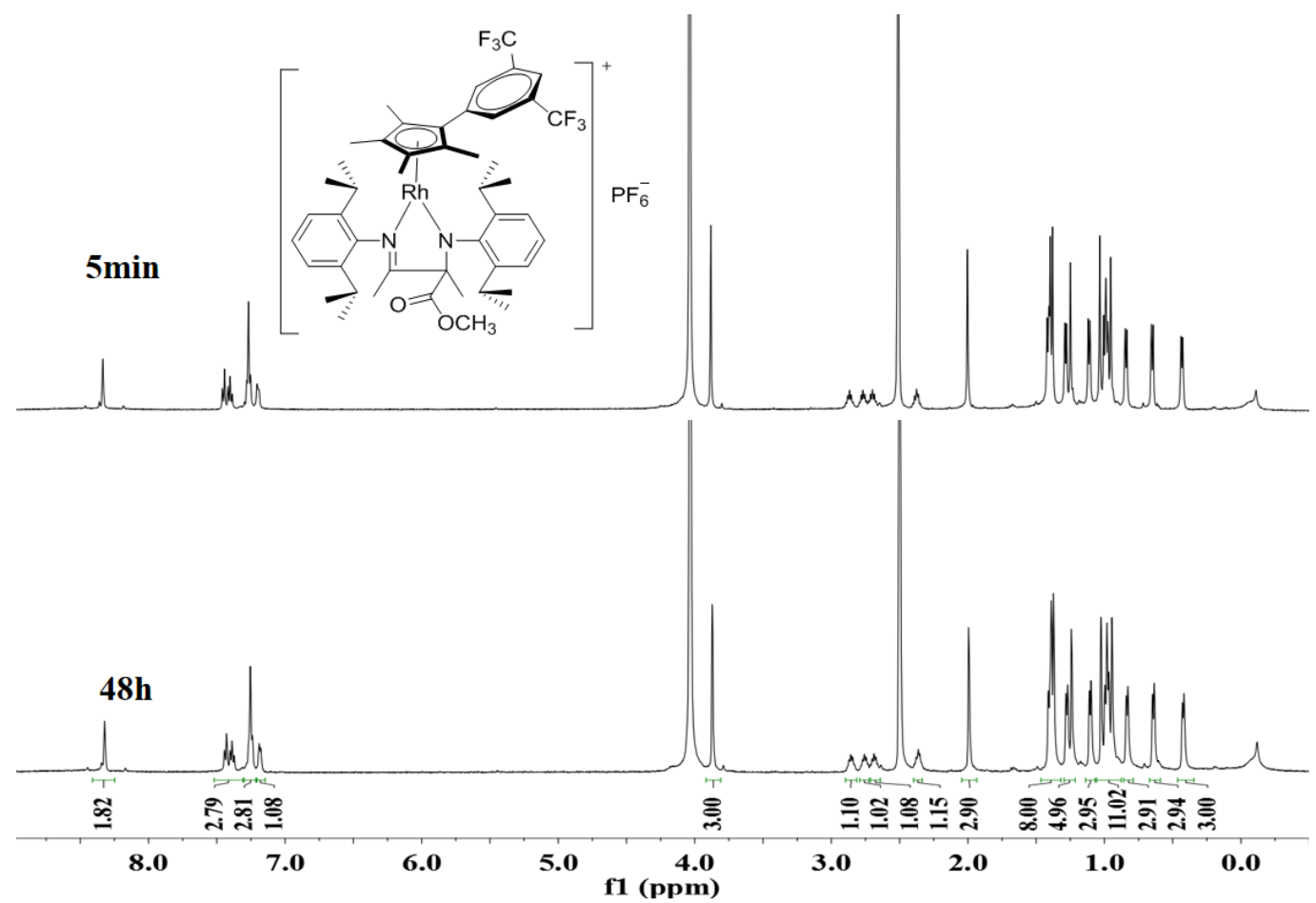

Figure S34. Time-dependent ${ }^{1} \mathrm{H}$ NMR spectroscopic stability study for $\mathbf{R h 5}$ in $75 \%$ DMSO- $d_{6} / 25 \%$ phosphate-buffered saline (PBS) $\left(\mathrm{pH} \approx 7.2\right.$, PBS is prepared from $\mathrm{D}_{2} \mathrm{O}$ ) over $48 \mathrm{~h}$. 


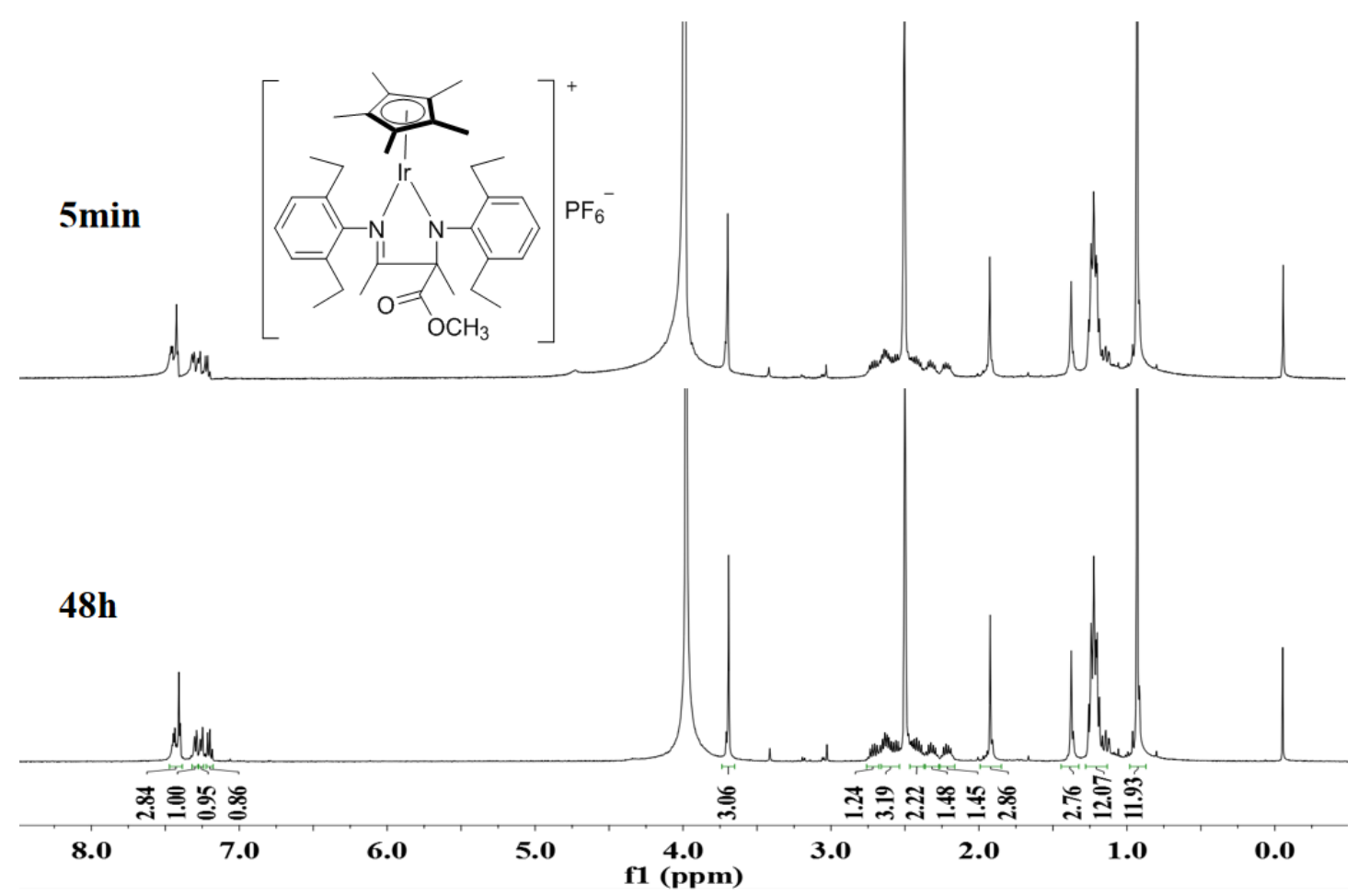

Figure S35. Time-dependent ${ }^{1} \mathrm{H}$ NMR spectroscopic stability study for Ir1 in $75 \%$ DMSO- $d_{6} / 25 \%$ phosphate-buffered saline (PBS) $\left(\mathrm{pH} \approx 7.2\right.$, PBS is prepared from $\mathrm{D}_{2} \mathrm{O}$ ) over $48 \mathrm{~h}$.

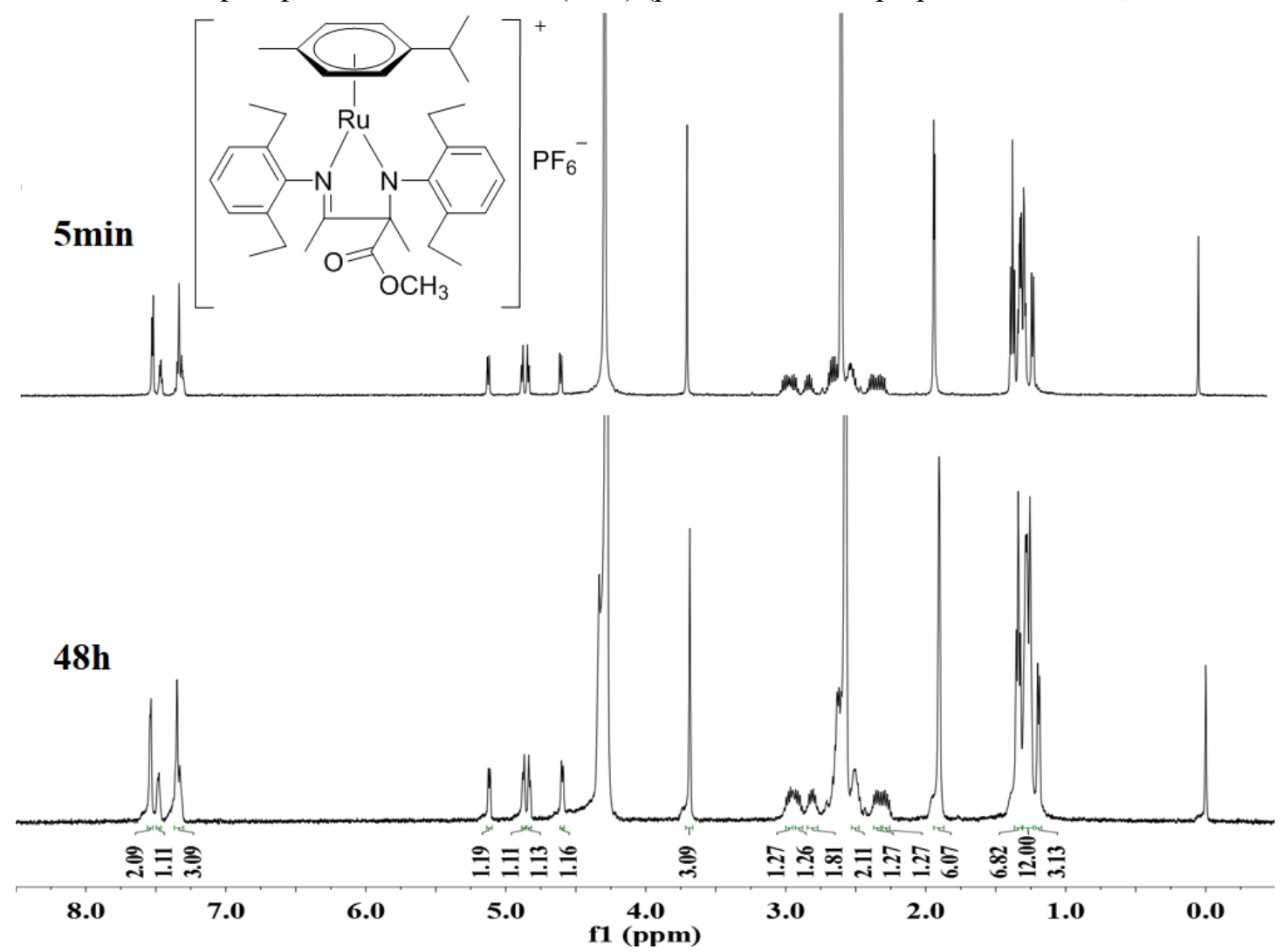

Figure S36. Time-dependent ${ }^{1} \mathrm{H}$ NMR spectroscopic stability study for Ru1 in $75 \%$ DMSO- $d_{6} / 25 \%$ phosphate-buffered saline (PBS) $\left(\mathrm{pH} \approx 7.2\right.$, PBS is prepared from $\mathrm{D}_{2} \mathrm{O}$ ) over $48 \mathrm{~h}$. 


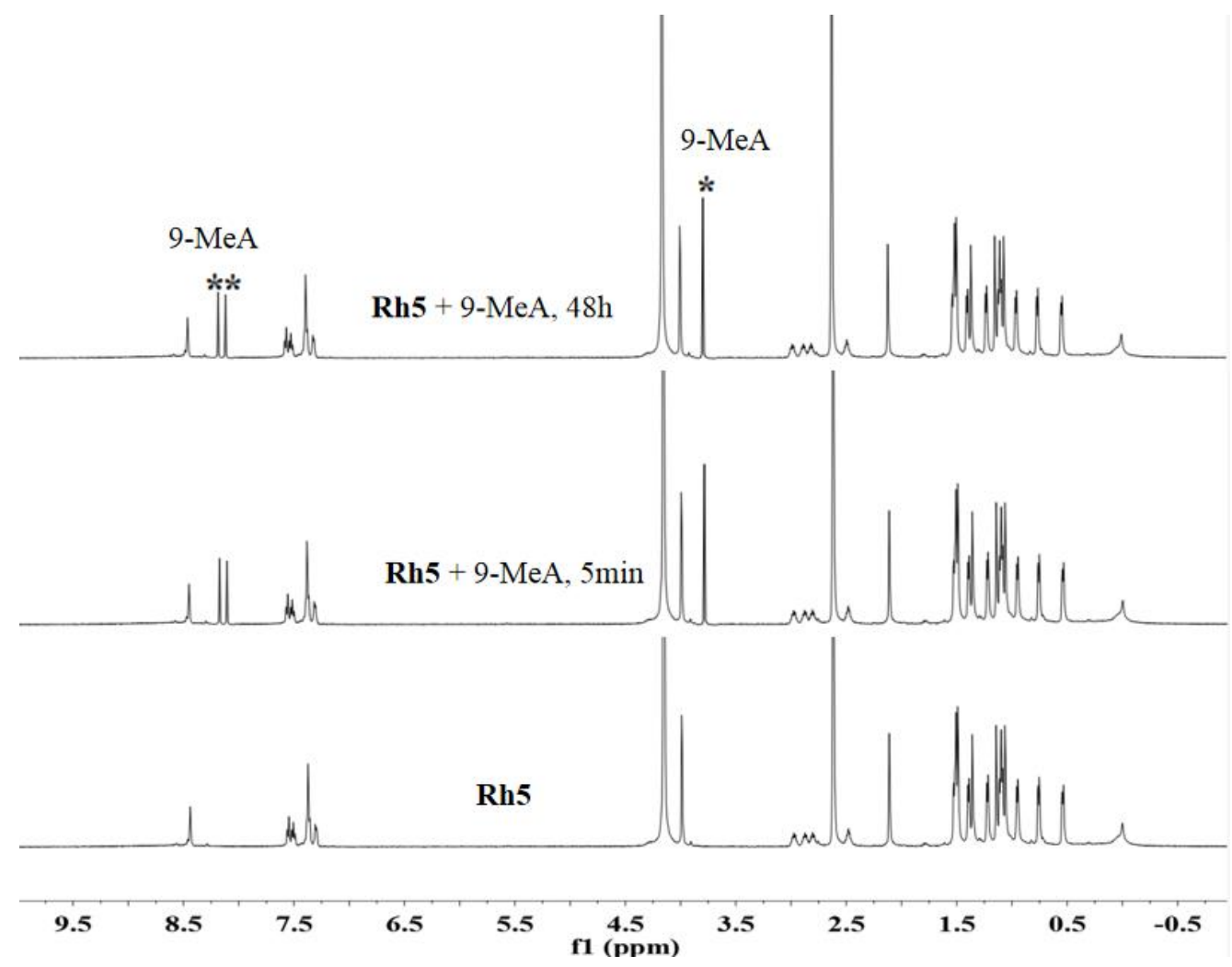

Figure S37. ${ }^{1} \mathrm{H}$ NMR spectroscopic study of the reaction between $\mathbf{R h 5}$ and 9-MeA at molar ratios of $1: 1 \mathrm{in} 70 \%$ DMSO- $d_{6} / 30 \% \mathrm{D}_{2} \mathrm{O}$ analyzed after $5 \mathrm{~min}$ and $48 \mathrm{~h}$.

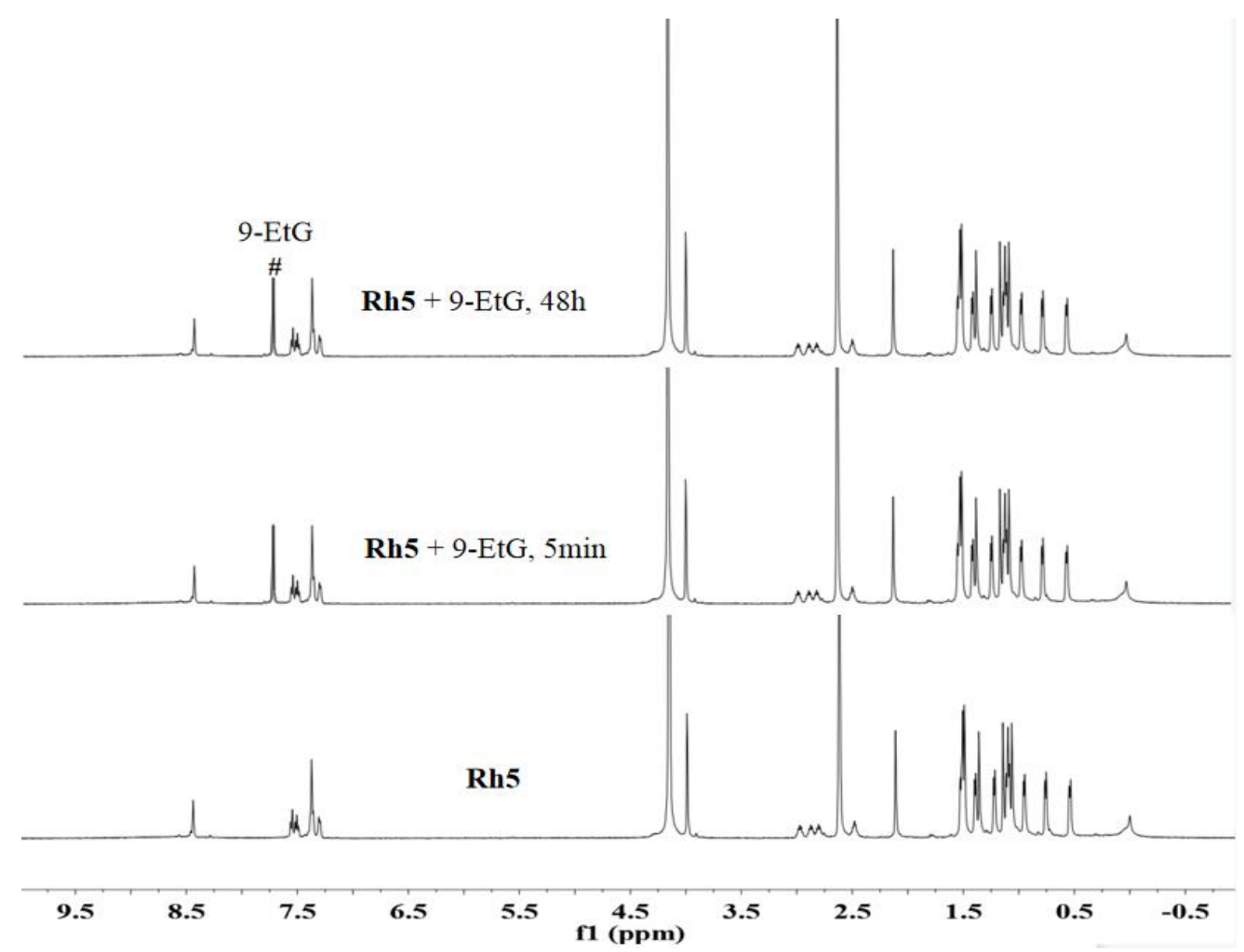

Figure S38. ${ }^{1} \mathrm{H}$ NMR spectroscopic study of the reaction between $\mathbf{R h 5}$ and 9-EtG at molar ratios of $1: 1$ in $70 \%$ DMSO- $d_{6} / 30 \% \mathrm{D}_{2} \mathrm{O}$ analyzed after $5 \mathrm{~min}$ and $48 \mathrm{~h}$. 


\section{Rh5}

\section{Control}

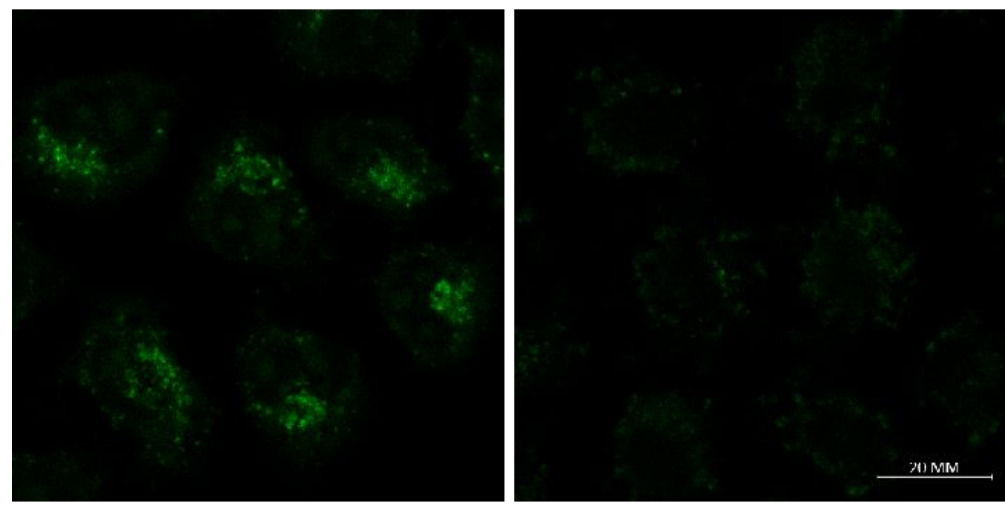

Figure S39. The left figure is the laser confocal diagram of A549 cells incubated with $\mathbf{R h 5}$, and the right figure is the laser confocal diagram of A549 cells not incubated with Rh5. Scale bar: 20 $\mu \mathrm{m}, \lambda_{\mathrm{ex}}=405 \mathrm{~nm}, \lambda_{\mathrm{em}}=430-490 \mathrm{~nm}$.

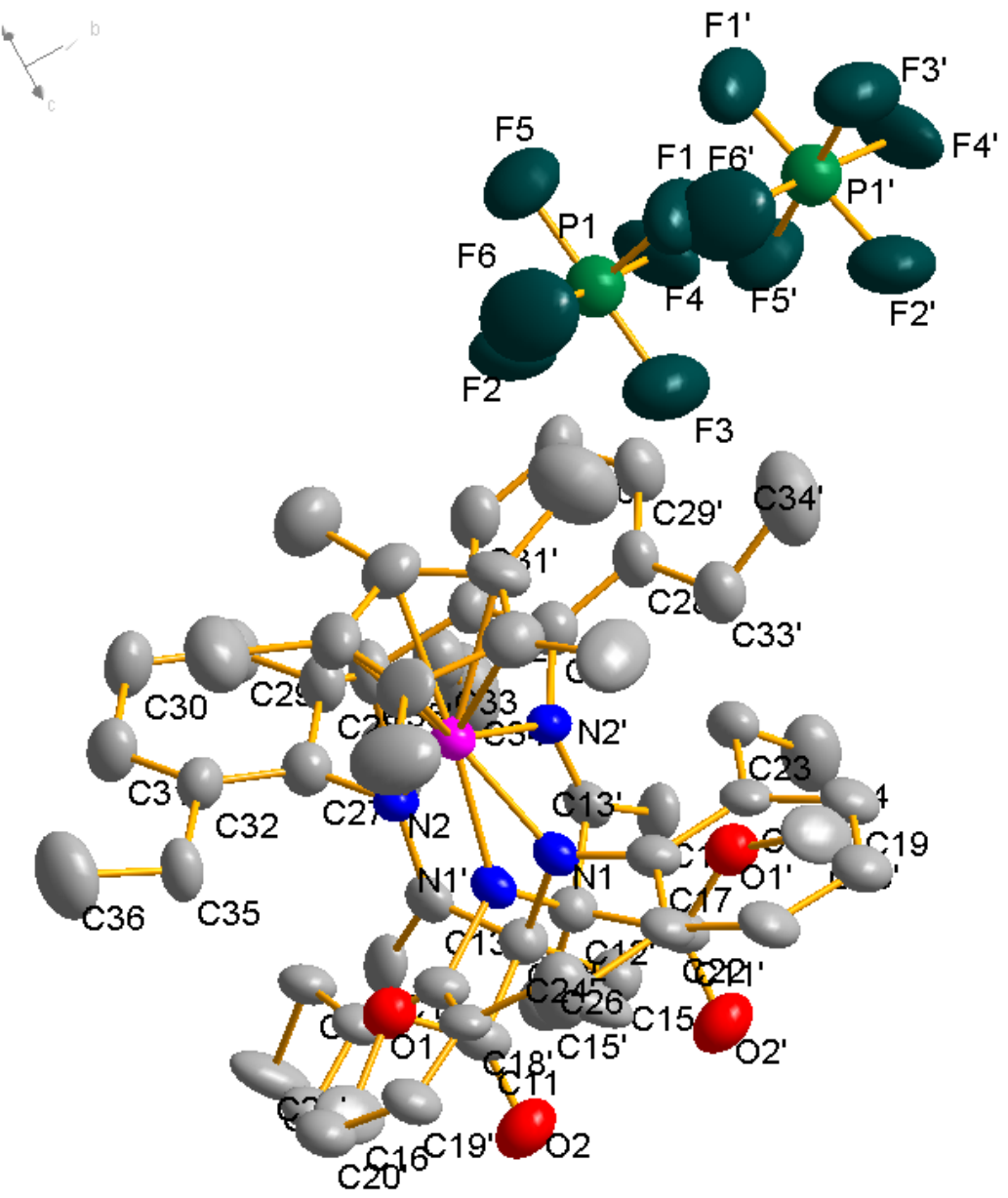

Figure S40. The disorders in the crystal structure of Ir1. 
Table S1. Crystallographic data for Rh2.

\begin{tabular}{ll}
\hline & Rh2 \\
\hline formula & $\mathrm{C}_{41} \mathrm{H}_{60} \mathrm{Cl}_{2} \mathrm{~F}_{6} \mathrm{~N}_{2} \mathrm{O}_{2} \mathrm{PRh}$ \\
$\mathrm{MW}$ & 931.69 \\
cryst & Red block \\
cryst size $(\mathrm{mm})$ & $0.40 \times 0.10 \times 0.05$ \\
$\lambda(\AA)$ & 0.71073 \\
temp $(\mathrm{K})$ & 298 \\
cryst syst & Monoclinic \\
space group & $\mathrm{C} 2$ \\
$\mathrm{a}(\AA)$ & $24.581(2)$ \\
$\mathrm{b}(\AA)$ & $11.7731(11)$ \\
$\mathrm{c}(\AA)$ & $17.6110(16)$ \\
$\alpha\left(^{\circ}\right)$ & 90 \\
$\beta\left(^{\circ}\right)$ & $122.310(5)$ \\
$\gamma\left({ }^{\circ}\right)$ & 90 \\
vol $\left(\AA^{3}\right)$ & $4307.5(7)$ \\
$\mathrm{Z}$ & 4 \\
density $($ calc $)\left(\mathrm{Mg} \cdot \mathrm{m}^{-3}\right)$ & 1.437 \\
abs coeff $\left(\mathrm{mm}{ }^{-1}\right)$ & 0.620 \\
$\mathrm{~F}(000)$ & 1936 \\
$\theta$ range (deg) & 1.99 to 25.02 \\
index ranges & $-25 \leq \mathrm{h} \leq 29,-14 \leq \mathrm{k} \leq 13,-20 \leq 1 \leq 20$ \\
reflns collected & 11070 \\
indep reflns & $7062[\mathrm{R}(\mathrm{int})=0.0598]$ \\
data / restraints / params & $7062 / 621 / 516$ \\
final R indices $[\mathrm{I}>2 \sigma(\mathrm{I})]$ & $\mathrm{R} 1=0.0816, \mathrm{wR} 2=0.2038$ \\
$\mathrm{R}$ indices $($ all data $)$ & $\mathrm{R} 1=0.1109, \mathrm{wR} 2=0.2368$ \\
$\mathrm{GOF}$ & 1.068 \\
largest diff peak and hole $\left(\mathrm{e} \AA{ }^{-3}\right)$ & 0.928 and -1.084 \\
\hline &
\end{tabular}

Table S2. Selected bond lengths $(\AA)$ and angles $\left(^{\circ}\right)$ for $\mathbf{R h 2}$.

\begin{tabular}{ll}
\hline & Rh2 \\
\hline & $2.153(10)$ \\
Rh-C(cyclopentadienyl) & $2.156(13)$ \\
& $2.161(14)$ \\
& $2.176(11)$ \\
Rh-C (centroid) & $2.215(11)$ \\
Rh1-N1 & 1.6943 \\
Rh1-N2 & $1.999(8)$ \\
N1-Rh1-N2 & $2.026(10)$ \\
\hline
\end{tabular}


Table S3. Crystallographic data for Ir1.

\begin{tabular}{ll}
\hline & Ir 1 \\
\hline formula & $\mathrm{C}_{36} \mathrm{H}_{50} \mathrm{~F}_{6} \mathrm{IrN}_{2} \mathrm{O}_{2} \mathrm{P}$ \\
$\mathrm{MW}$ & 879.95 \\
cryst & Red block \\
cryst size $(\mathrm{mm})$ & $0.35 \times 0.32 \times 0.10$ \\
$\lambda(\AA)$ & 0.71073 \\
temp $(\mathrm{K})$ & 298 \\
cryst syst & Monoclinic \\
space group & $\mathrm{P} 2(1)$ \\
$\mathrm{a}(\AA)$ & $12.3064(11)$ \\
$\mathrm{b}(\AA)$ & $11.4017(9)$ \\
$\mathrm{c}(\AA)$ & $13.2916(12)$ \\
$\alpha\left(^{\circ}\right)$ & 90 \\
$\beta\left(^{\circ}\right)$ & $90.671(2)$ \\
$\gamma\left({ }^{\circ}\right)$ & 90 \\
vol $\left(\AA^{3}\right)$ & $1864.9(3)$ \\
$\mathrm{Z}$ & 2 \\
density $($ calc $)\left(\mathrm{Mg} \cdot \mathrm{m}^{-3}\right)$ & 1.567 \\
abs coeff $\left(\mathrm{mm}{ }^{-1}\right)$ & 3.686 \\
$\mathrm{~F}(000)$ & 884 \\
$\theta$ range $($ deg $)$ & 2.24 to 25.02 \\
index ranges & $-14 \leq \mathrm{h} \leq 9,-13 \leq \mathrm{k} \leq 13,-14 \leq 1 \leq 15$ \\
reflns collected & 9288 \\
indep reflns & $6269[\mathrm{R}(\mathrm{int})=0.0442]$ \\
data / restraints / params & $6269 / 1448 / 513$ \\
final R indices $[\mathrm{I}>2 \sigma(\mathrm{I})]$ & $\mathrm{R} 1=0.0500, \mathrm{wR} 2=0.1152$ \\
$\mathrm{R}$ indices $(\mathrm{all}$ data $)$ & $\mathrm{R} 1=0.0649, \mathrm{wR} 2=0.1214$ \\
$\mathrm{GOF}$ & 1.054 \\
largest diff peak and hole $\left(\mathrm{e} \AA \AA^{-3}\right)$ & 1.408 and -1.295 \\
\hline &
\end{tabular}

Table S4. Selected bond lengths $(\AA)$ and angles $\left(^{\circ}\right)$ for Ir1.

\begin{tabular}{ll}
\hline & Ir1 \\
\hline & $2.114(9)$ \\
Ir-C(cyclopentadienyl) & $2.154(12)$ \\
& $2.187(12)$ \\
& $2.221(11)$ \\
Ir-C (centroid) & $2.177(11)$ \\
Ir1-N1 & 1.8231 \\
Ir1-N2 & $1.916(11)$ \\
N1-Ir1-N2 & $1.94(2)$ \\
\hline
\end{tabular}


Symmetry transformations used to generate equivalent atoms:

Table S5. Anisotropic displacement parameters $\left(\AA^{2} \times 10^{3}\right)$ for Ir1. The anisotropic displacement factor exponent takes the form: $-2 \pi^{2}\left[h^{2} a^{* 2} U^{11}+\ldots+2 h k a^{*} b^{*} U^{12}\right]$.

\begin{tabular}{|c|c|c|c|c|c|c|}
\hline & $\mathrm{U}^{11}$ & $\mathrm{U}^{22}$ & $\mathrm{U}^{33}$ & $\mathrm{U}^{23}$ & $\mathrm{U}^{13}$ & $\mathrm{U}^{12}$ \\
\hline $\operatorname{Ir}(1)$ & $37(1)$ & $31(1)$ & $29(1)$ & $0(1)$ & $1(1)$ & $-3(1)$ \\
\hline $\mathrm{P}(1)$ & $66(3)$ & 61(2) & $43(2)$ & $-3(7)$ & $-5(2)$ & $0(7)$ \\
\hline $\mathrm{F}(1)$ & 131(9) & $86(9)$ & $89(8)$ & $28(8)$ & $32(7)$ & $40(9)$ \\
\hline $\mathrm{F}(2)$ & $105(10)$ & $116(10)$ & $106(10)$ & $27(9)$ & $36(9)$ & $-15(9)$ \\
\hline $\mathrm{F}(3)$ & $90(9)$ & $123(10)$ & $106(10)$ & $34(9)$ & $24(8)$ & $8(8)$ \\
\hline $\mathrm{F}(4)$ & 132(10) & $83(8)$ & $69(8)$ & $-12(6)$ & $-8(8)$ & $-61(8)$ \\
\hline $\mathrm{F}(5)$ & 97(9) & 118(11) & $55(7)$ & $3(7)$ & $17(6)$ & $17(7)$ \\
\hline $\mathrm{F}(6)$ & 149(11) & $166(12)$ & $84(9)$ & $-36(9)$ & $-14(9)$ & $-32(11)$ \\
\hline $\mathrm{P}\left(1^{\prime}\right)$ & $66(3)$ & 61(2) & $43(2)$ & $-3(7)$ & $-5(2)$ & $0(7)$ \\
\hline $\mathrm{F}\left(1^{\prime}\right)$ & 131(9) & $86(9)$ & $89(8)$ & $28(8)$ & $32(7)$ & $40(9)$ \\
\hline $\mathrm{F}\left(2^{\prime}\right)$ & $105(10)$ & $116(10)$ & $106(10)$ & $27(9)$ & $36(9)$ & $-15(9)$ \\
\hline $\mathrm{F}\left(3^{\prime}\right)$ & $90(9)$ & $123(10)$ & 106(10) & $34(9)$ & $24(8)$ & $8(8)$ \\
\hline $\mathrm{F}\left(4^{\prime}\right)$ & 132(10) & $83(8)$ & $69(8)$ & $-12(6)$ & $-8(8)$ & $-61(8)$ \\
\hline $\mathrm{F}\left(5^{\prime}\right)$ & $97(9)$ & 118(11) & $55(7)$ & $3(7)$ & $17(6)$ & $17(7)$ \\
\hline $\mathrm{F}\left(6^{\prime}\right)$ & 149(11) & $166(12)$ & $84(9)$ & $-36(9)$ & $-14(9)$ & $-32(11)$ \\
\hline $\mathrm{N}(1)$ & $41(4)$ & $29(4)$ & $28(4)$ & $1(5)$ & $-2(3)$ & $-5(5)$ \\
\hline $\mathrm{N}(2)$ & $37(4)$ & $33(4)$ & $36(4)$ & $3(4)$ & $9(3)$ & $-2(5)$ \\
\hline $\mathrm{N}\left(1^{\prime}\right)$ & 41(4) & $29(4)$ & $28(4)$ & $1(5)$ & $-2(3)$ & $-5(5)$ \\
\hline $\mathrm{N}\left(2^{\prime}\right)$ & $37(4)$ & $33(4)$ & $36(4)$ & $3(4)$ & $9(3)$ & $-2(5)$ \\
\hline $\mathrm{O}(1)$ & $42(5)$ & $50(5)$ & $46(6)$ & $-1(6)$ & $2(5)$ & $0(6)$ \\
\hline $\mathrm{O}(2)$ & $53(5)$ & $75(8)$ & $55(6)$ & $-5(8)$ & 11(5) & $9(8)$ \\
\hline $\mathrm{O}\left(1^{\prime}\right)$ & $42(5)$ & $50(5)$ & $46(6)$ & $-1(6)$ & $2(5)$ & $0(6)$ \\
\hline $\mathrm{O}\left(2^{\prime}\right)$ & $53(5)$ & $75(8)$ & $55(6)$ & $-5(8)$ & 11(5) & $9(8)$ \\
\hline $\mathrm{C}(1)$ & $67(5)$ & 64(7) & $22(4)$ & $-20(5)$ & $-3(4)$ & $-9(6)$ \\
\hline $\mathrm{C}(2)$ & $80(6)$ & $51(5)$ & $53(6)$ & $-8(5)$ & $24(5)$ & $4(5)$ \\
\hline $\mathrm{C}(3)$ & $56(5)$ & $67(7)$ & $49(5)$ & $-6(5)$ & $11(5)$ & $0(5)$ \\
\hline $\mathrm{C}(4)$ & $72(6)$ & $51(5)$ & $53(6)$ & $10(5)$ & $11(5)$ & $-18(5)$ \\
\hline$C(5)$ & $60(6)$ & $65(6)$ & $51(6)$ & $7(5)$ & $4(5)$ & $3(5)$ \\
\hline$C(6)$ & $108(10)$ & 136(11) & $66(8)$ & $-12(8)$ & $6(8)$ & $-30(9)$ \\
\hline $\mathrm{C}(7)$ & 131(10) & $68(8)$ & 99(9) & $7(8)$ & 19(9) & $13(8)$ \\
\hline$C(8)$ & $70(7)$ & $92(10)$ & $98(8)$ & $-4(8)$ & $14(6)$ & $11(7)$ \\
\hline $\mathrm{C}(9)$ & 131(11) & 108(10) & 139(11) & $7(10)$ & $-2(11)$ & $-27(10)$ \\
\hline
\end{tabular}




\begin{tabular}{|c|c|c|c|c|c|c|}
\hline$C(10)$ & 100(9) & $99(8)$ & $55(7)$ & $35(7)$ & 1(7) & $34(7)$ \\
\hline $\mathrm{C}(11)$ & $41(5)$ & $45(5)$ & $44(5)$ & $12(6)$ & $1(5)$ & $-7(6)$ \\
\hline$C(12)$ & $42(4)$ & $39(5)$ & $36(4)$ & $5(6)$ & 2(4) & $1(6)$ \\
\hline $\mathrm{C}(13)$ & $50(5)$ & $31(5)$ & $39(5)$ & $-4(6)$ & $2(4)$ & $-10(6)$ \\
\hline$C(14)$ & $51(7)$ & $40(9)$ & $48(7)$ & $-19(7)$ & $-1(6)$ & $2(8)$ \\
\hline$C(15)$ & $63(7)$ & $43(8)$ & $45(6)$ & $0(8)$ & $7(6)$ & $1(8)$ \\
\hline$C(16)$ & $56(9)$ & $69(9)$ & $46(13)$ & $34(9)$ & $-19(9)$ & $9(12)$ \\
\hline$C(17)$ & $45(5)$ & $44(5)$ & $37(5)$ & $7(6)$ & $5(4)$ & $-8(6)$ \\
\hline $\mathrm{C}(18)$ & $46(6)$ & $41(6)$ & $35(6)$ & $8(6)$ & $13(5)$ & $-7(6)$ \\
\hline $\mathrm{C}(19)$ & $56(7)$ & $44(6)$ & $48(7)$ & $16(6)$ & $2(6)$ & $-7(6)$ \\
\hline $\mathrm{C}(20)$ & $56(8)$ & $50(6)$ & $47(6)$ & $14(8)$ & $3(7)$ & $-6(7)$ \\
\hline $\mathrm{C}(21)$ & $52(7)$ & $47(6)$ & $54(6)$ & $23(6)$ & $0(6)$ & $-5(6)$ \\
\hline $\mathrm{C}(22)$ & $46(6)$ & $40(5)$ & $41(6)$ & $15(5)$ & $5(5)$ & $-4(5)$ \\
\hline $\mathrm{C}(23)$ & $55(7)$ & $41(7)$ & $48(7)$ & $-5(6)$ & $11(6)$ & $-10(6)$ \\
\hline $\mathrm{C}(24)$ & $68(12)$ & $66(13)$ & $97(14)$ & $-16(11)$ & $-13(12)$ & $6(11)$ \\
\hline $\mathrm{C}(25)$ & $47(6)$ & $43(6)$ & $49(6)$ & $11(6)$ & $8(6)$ & $-11(6)$ \\
\hline$C(26)$ & $69(12)$ & $64(11)$ & $74(12)$ & $44(12)$ & $-18(10)$ & $-26(13)$ \\
\hline $\mathrm{C}(27)$ & $50(5)$ & $44(4)$ & $48(5)$ & $-4(6)$ & $2(4)$ & $1(6)$ \\
\hline$C(28)$ & $53(6)$ & $39(5)$ & $57(6)$ & $-11(6)$ & $2(5)$ & $1(6)$ \\
\hline $\mathrm{C}(29)$ & $56(6)$ & $43(6)$ & $67(7)$ & $0(6)$ & $-8(6)$ & $8(6)$ \\
\hline $\mathrm{C}(30)$ & $48(6)$ & $52(7)$ & $63(8)$ & $-10(6)$ & $-5(6)$ & $14(7)$ \\
\hline $\mathrm{C}(31)$ & $55(6)$ & $51(6)$ & $58(7)$ & $-15(6)$ & $-2(6)$ & $4(6)$ \\
\hline$C(32)$ & $46(5)$ & $41(5)$ & $52(6)$ & $-1(5)$ & $6(5)$ & $7(6)$ \\
\hline$C(33)$ & $61(7)$ & $46(7)$ & $65(7)$ & $-9(6)$ & $-1(6)$ & $0(7)$ \\
\hline $\mathrm{C}(34)$ & $133(15)$ & $70(13)$ & $111(15)$ & $-18(11)$ & $-23(14)$ & $13(12)$ \\
\hline $\mathrm{C}(35)$ & $57(6)$ & $36(5)$ & $55(6)$ & $-11(6)$ & $-7(6)$ & $8(6)$ \\
\hline$C(36)$ & $126(15)$ & $64(11)$ & $89(14)$ & $-18(11)$ & $-21(13)$ & $3(12)$ \\
\hline $\mathrm{C}\left(11^{\prime}\right)$ & $41(5)$ & $45(5)$ & $44(5)$ & $12(6)$ & $1(5)$ & $-7(6)$ \\
\hline $\mathrm{C}\left(12^{\prime}\right)$ & $42(4)$ & $39(5)$ & $36(4)$ & $5(6)$ & $2(4)$ & $1(6)$ \\
\hline$C\left(13^{\prime}\right)$ & $50(5)$ & $31(5)$ & $39(5)$ & $-4(6)$ & $2(4)$ & $-10(6)$ \\
\hline$C\left(14^{\prime}\right)$ & $51(7)$ & 40(9) & $48(7)$ & $-19(7)$ & $-1(6)$ & $2(8)$ \\
\hline$C\left(15^{\prime}\right)$ & $63(7)$ & $43(8)$ & $45(6)$ & $0(8)$ & $7(6)$ & $1(8)$ \\
\hline$C\left(16^{\prime}\right)$ & $56(9)$ & $69(9)$ & $46(13)$ & $34(9)$ & $-19(9)$ & $9(12)$ \\
\hline $\mathrm{C}\left(17^{\prime}\right)$ & $45(5)$ & $44(5)$ & $37(5)$ & $7(6)$ & $5(4)$ & $-8(6)$ \\
\hline$C\left(18^{\prime}\right)$ & $46(6)$ & $41(6)$ & $35(6)$ & $8(6)$ & $13(5)$ & $-7(6)$ \\
\hline$C\left(19^{\prime}\right)$ & $56(7)$ & $44(6)$ & $48(7)$ & $16(6)$ & $2(6)$ & $-7(6)$ \\
\hline$C\left(20^{\prime}\right)$ & $56(8)$ & $50(6)$ & $47(6)$ & $14(8)$ & $3(7)$ & $-6(7)$ \\
\hline$C\left(21^{\prime}\right)$ & $52(7)$ & $47(6)$ & $54(6)$ & $23(6)$ & $0(6)$ & $-5(6)$ \\
\hline
\end{tabular}




$\begin{array}{lcccccc}\mathrm{C}\left(22^{\prime}\right) & 46(6) & 40(5) & 41(6) & 15(5) & 5(5) & -4(5) \\ \mathrm{C}\left(23^{\prime}\right) & 55(7) & 41(7) & 48(7) & -5(6) & 11(6) & -10(6) \\ \mathrm{C}\left(24^{\prime}\right) & 68(12) & 66(13) & 97(14) & -16(11) & -13(12) & 6(11) \\ \mathrm{C}\left(25^{\prime}\right) & 47(6) & 43(6) & 49(6) & 11(6) & 8(6) & -11(6) \\ \mathrm{C}\left(26^{\prime}\right) & 69(12) & 64(11) & 74(12) & 44(12) & -18(10) & -26(13) \\ \mathrm{C}\left(27^{\prime}\right) & 50(5) & 44(4) & 48(5) & -4(6) & 2(4) & 1(6) \\ \mathrm{C}\left(28^{\prime}\right) & 53(6) & 39(5) & 57(6) & -11(6) & 2(5) & 1(6) \\ \mathrm{C}\left(29^{\prime}\right) & 56(6) & 43(6) & 67(7) & 0(6) & -8(6) & 8(6) \\ \mathrm{C}\left(30^{\prime}\right) & 48(6) & 52(7) & 63(8) & -10(6) & -5(6) & 14(7) \\ \mathrm{C}\left(31^{\prime}\right) & 55(6) & 51(6) & 58(7) & -15(6) & -2(6) & 4(6) \\ \mathrm{C}\left(32^{\prime}\right) & 46(5) & 41(5) & 52(6) & -1(5) & 6(5) & 7(6) \\ \mathrm{C}\left(33^{\prime}\right) & 61(7) & 46(7) & 65(7) & -9(6) & -1(6) & 0(7) \\ \mathrm{C}\left(34^{\prime}\right) & 133(15) & 70(13) & 111(15) & -18(11) & -23(14) & 13(12) \\ \mathrm{C}\left(35^{\prime}\right) & 57(6) & 36(5) & 55(6) & -11(6) & -7(6) & 8(6) \\ \mathrm{C}\left(36^{\prime}\right) & 126(15) & 64(11) & 89(14) & -18(11) & -21(13) & 3(12)\end{array}$

Table S6. Cell cycle analysis carried out by flow cytometry using PI staining after exposing A549 cells to complex Rh5.

\begin{tabular}{lllll}
\hline & & \multicolumn{3}{c}{ Population $(\%)$} \\
Complex & Rh concentration & $\mathrm{G}_{1}$ phase & S phase & $\mathrm{G}_{2} / \mathrm{M}$ phase \\
\hline \multirow{2}{*}{$\mathbf{R h 5}$} & $0.25 \times \mathrm{IC}_{50}$ & $90.32 \pm 1.3$ & $7.00 \pm 0.5$ & $2.68 \pm 0.7$ \\
& $0.5 \times \mathrm{IC}_{50}$ & $83.65 \pm 1.2$ & $11.46 \pm 0.6$ & $4.88 \pm 1.0$ \\
control & $1.0 \times \mathrm{IC}_{50}$ & $84.81 \pm 0.7$ & $12.53 \pm 0.4$ & $2.67 \pm 0.5$ \\
\hline
\end{tabular}

Table S7. Flow cytometry analysis to determine the percentages of apoptotic cells, using Annexin V -FITC vs PI staining, after exposing A549 cells to complex Rh5.

\begin{tabular}{llllll}
\hline \multirow{5}{*}{ Complex } & $\mathrm{Rh}$ & Vopulation (\%) & \\
& Concentration & & Early & Late & Non-viable \\
& $0.5 \times \mathrm{IC}_{50}$ & $80.41 \pm 1.3$ & $0.42 \pm 0.7$ & $11.74 \pm 0.9$ & $7.44 \pm 0.6$ \\
$\mathbf{2}$ Rh5 & $1.0 \times \mathrm{IC}_{50}$ & $73.91 \pm 0.8$ & $1.17 \pm 1.1$ & $13.83 \pm 1.2$ & $12.26 \pm 0.4$ \\
& & $89.09 \pm 0.4$ & $0.59 \pm 0.4$ & $4.91 \pm 0.2$ & $5.41 \pm 0.2$ \\
\hline
\end{tabular}

